\title{
The flora of land plants (bryophytes and vascular plants) in Wangpicheon Ecosystem and Landscape Conservation Area (ELCA), Korea
}

\author{
Seung Hyuk LEE, Jin-Kap AHN ${ }^{1}$, Seung Jin PARK ${ }^{1}$, Chul Hwan KIM ${ }^{2}$ and Seung Se CHOI ${ }^{*}$ \\ National Baedudaegan Arboretum, Korea Institute of Arboretum Management, Bonghwa, 36209, Korea \\ ${ }^{1}$ Division of Life Sciences, Jeonbuk National University, Jeonju 54896, Korea \\ ${ }^{2}$ Sung-ho Green Tech, Jangseong 57248, Korea \\ ${ }^{3}$ Team of National Ecosystem Survey, National Institute of Ecology, Seocheon 33657, Korea \\ (Received 14 May 2020; Revised 6 July 2020; Accepted 19 September 2020)
}

\begin{abstract}
This study presents the flora of nonvascular plants (bryophytes) and vascular plants within the Wangpicheon Ecosystem and Landscape Conservation Area in Korea. The time of the survey was divided into four seasons. The fieldwork was conducted for a total of 18 days from November of 2016 to October of 2017. The land plants in the Wangpicheon conservation area were identified as 758 taxa with 164 families, 455 genera, 698 species, 10 subspecies, 47 varieties and 3 forms. Among them, bryophytes amounted to 122 taxa and vascular plants numbered 636 taxa. Native plant amounted to 693 taxa. In total, there are 113 floristic target species in Korea, including one level V taxon, in this case Swertia wilfordii; six level IV taxa; 31 level III taxa; 38 level II taxa; and 37 level I taxa. There are nine endemic plants, including Sillaphyton (=Peucedanum) podagraria, which is the endemic genus; two rare plants; fifteen northern plants; and one southern plant as target plants adaptable to climate change. Also, there are forty-six naturalized plants and five ecosystem-disturbance organisms. The results of this study suggest several species that should be preserved and can serve as basic information with which to establish conservation and management plans for the Wangpicheon conservation area.
\end{abstract}

Keywords: Wangpicheon, land plants, bryophytes, native plant, management

생태·경관보전지역은 자연상태가 원시성을 유지하거 나 생물다양성이 풍부하여 생태적으로 우수한 지역으로 지형·지질 등 무생물적인 요소도 고려되어 특별히 보전할 가치가 있는 지역을 자연환경보전법에 의거 보호지역으 로 지정하고 보호·관리하는 곳이다. 우리나라는 1989년부 터 2020년까지 총 33 개의 생태·경관보전지역을 지정하였다. 이 중 환경부 지정지역은 9 개이며, 면적은 총 $248.03 \mathrm{~km}^{2}$ 이 고 시·도에서 지정한 지역은 24개로, 면적은 총 $37.764 \mathrm{~km}^{2}$ 이다. 이 중 왕피천 유역은 2005년에 지정되고 2006년에 보호면적이 확대되었으며 면적은 $102,841 \mathrm{~km}^{2}$ 이다(Ahn et al., 2017). 이는 우리나라 생태·경관보전지역의 전체면적 중 최대 규모로 $41.5 \%$ 를 차지하고 있다. 왕피천 유역의 행 정구역은 경상북도 울진군에 $88 \%$, 영양군에 $12 \%$ 로 위치 한다. 왕피천 생태·경관보전지역은 지속가능한 보전 및 관리를 위하여 다음 3 가지로 지정·관리하고 있으며, 핵심 구역 $\left(45.35 \mathrm{~km}^{2}\right)$ 은 2005.10.14일에 고시되었고, 완충구역 $\left(55.64 \mathrm{~km}^{2}\right)$ 과 전이구역 $\left(1.85 \mathrm{~km}^{2}\right)$ 은 2006.12 .8 일에 고시되 었다. 사유지는 전체 면적 중 $5.9 \%$ 정도 해당된다(Park and Lee, 2017).

왕피천유역의 지질은 선캄브리아기의 지층으로 크게 북쪽은 율리층 $(\mathrm{pCEy})$ 이고 남쪽은 원남층 $(\mathrm{pCEw})$ 으로 대 비되며 이외에도 다른 지층들로 구성되어 있다(Kang and $\mathrm{Oh}, 2017)$. 지형은 산지지형과 하천지형으로 나눌 수 있으 며, 산지는 토르·새프롤라이트·산지습지 등이 있고, 하천 은 다양한 침식·퇴적 하천지형이 나타나며 기반암을 하방 침식하여 형성된 감입곡류하천이 특징적이다(Kang and $\mathrm{Oh}, 2017)$. 이곳의 토지 현황은 대부분 산림이고 기후환경 중 20 년간 연평균 기온은 $12^{\circ} \mathrm{C}$ 이며, 연평균 강수량은 $1,342.65 \mathrm{~mm}$ 이다(Kang and $\mathrm{Oh}, 2017) .2017$ 년에도 평균기 온이 $13.2^{\circ} \mathrm{C}$, 최저기온은 $-9^{\circ} \mathrm{C}$, 최고기온은 $37.1^{\circ} \mathrm{C}$ 이며 평 균상대습도는 $64.2 \%$ 이고 평균일조율은 $56.7 \%$ 였다(Korea Meteorological Administration, 2018). 왕피천 유역은 주민들

\footnotetext{
*Author for correspondence: hepaticae@nie.re.kr
} 
과의 의견수렴을 거쳐 보호지역으로 설정되고 보호되면 서 생물다양성이 높아지고 있다. 특히, geodiversity가 높아 다양한 생물서식지가 많으며 이에 맞게 생물종 또한 2,320 종으로 2012년 정밀조사 결과(1,762종)보다 다양성 이 많이 높아졌다. 멸종위기 야생생물은 산양, 수리부엉 이, 구렁이, 큰자색호랑꽃무지 등 12 종이 서식하고 한반 도 고유종도 32 종이 서식하는 것으로 알려졌으며 식생현 황도 $93 \%$ 이상이 생태자연도 1-2등급으로 이루어져 있어 이곳의 환경은 높이 평가받고 있다(Park and Lee, 2017).

이러한 왕피천 유역 주변 일대의 관속식물상 조사는 불 영사계곡과 통고산을 중심으로 560 분류군(Lee et al., 1976), 제 2 차 전국자연환경조사 일환으로 장군봉.통고산. 천축산에서 573분류군(Kim and Do, 2001), 불영계곡 일대 에서 641분류군(Oh and Shin, 2006), 왕피천을 중심으로 384분류군(Chung and Kim, 2003)이 조사된바 있다. 왕피천 생태·경관 보전지역의 정밀조사로는 대구지방환경청에 서 457분류군(Park and Lee, 2008), 국립환경과학원에서 613분류군(Hyun et al., 2012)을 확인하였다. 그러나 선행 연구들은 증거표본이 없거나 불분명하여 생물다양성이 높아지고 있는 왕피천 보전지역의 관속식물상 연구에 한 계가 있을 것으로 보인다. 또한 육상식물 중 비관속식물 에 속하는 선태식물(Bryophyte)은 우리나라에 925분류군
이 분포한다고 알려져 있으나(National Biodiversity Center, 2019) 아직 국내에서는 연구가 미비한 실정이며 왕피천 유역 일대에서도 조사가 이루어진 바 없다. 이에 본 연구 는 왕피천 생태·경관 보전지역의 관속식물상과 선태식물 상을 밝히고 육상식물의 종조성 특징과 육상식물의 지리 학적 중요성을 논하며, 이와 더불어 자연환경보전 등 보 호지역의 지속가능한 관리방안을 수립하고 개선하는 데, 기여하고자 하였다.

\section{재료 및 방법}

\section{조사지 개황}

경상북도의 왕피천은 영양군 수비면의 금장산 $(849 \mathrm{~m})$ 의 북서쪽 계곡에서 발원하여 신원리에서 북동쪽방면으 로 장수포천을 만나고 왕피천으로 합류하는 것으로 보는 관점이 가장 많으며, 울진군의 금강송면과 근남면을 거쳐 동해로 흘러들어가는 $60.95 \mathrm{~km}$ 길이의 지방 2 급하천이다. 왕피천 유역은 경상북도 울진군 금강송면과 근남면 그리 고 영양군 수비면에 위치하며, 백두대간의 정맥 중 하나 인 낙동정맥의 동쪽으로 북측의 천축산 $(653.3 \mathrm{~m})$, 서측의 통고산 $(1,066.5 \mathrm{~m})$, 동측의 남수산 $(437.7 \mathrm{~m})$ 소령산 $(590 \mathrm{~m})$. 대령산 $(652.5 \mathrm{~m})$ 자락과 남측의 금장산 $(848.4 \mathrm{~m})$-울련산

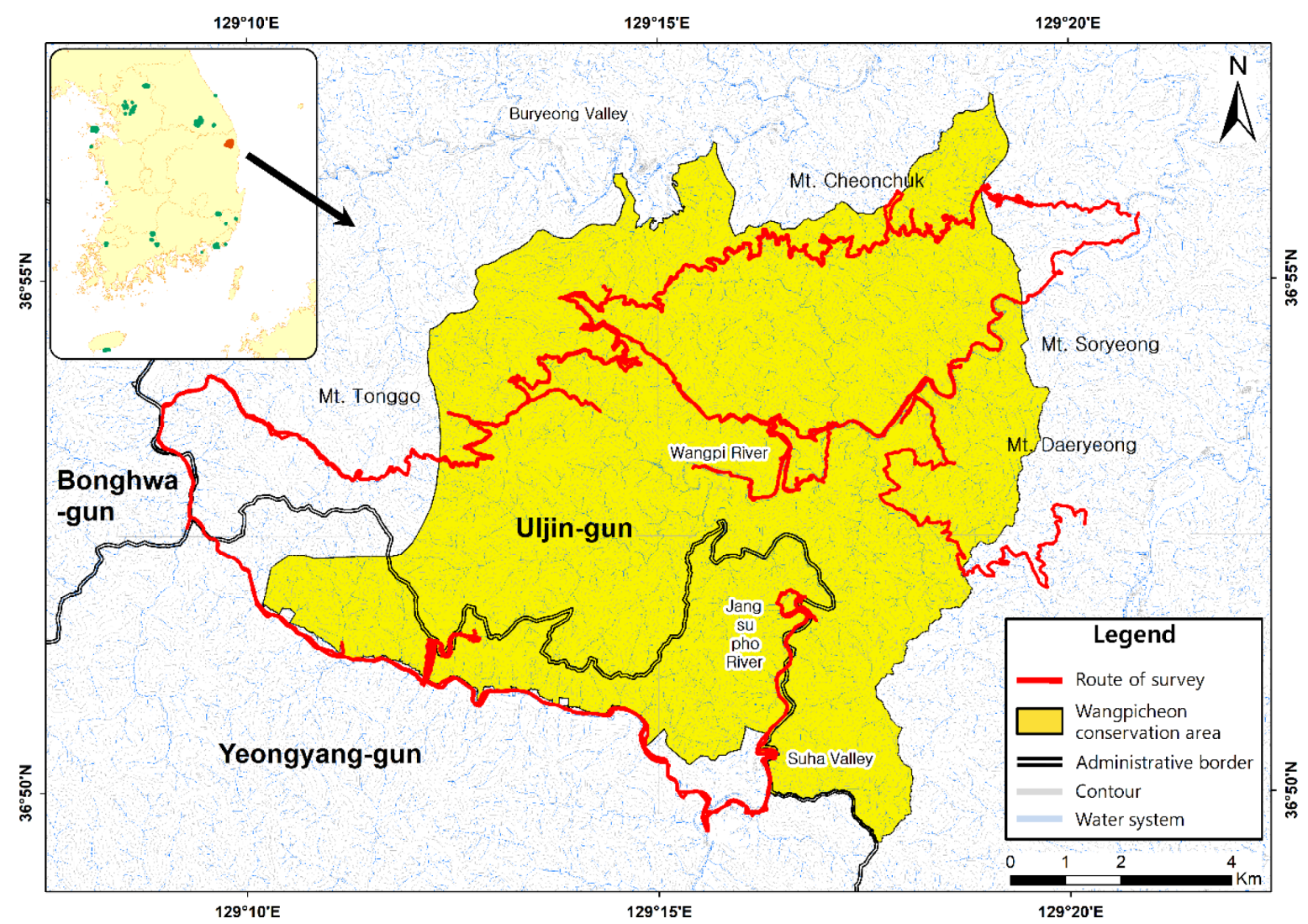

Fig. 1. The map of Wangpicheon watershed (study area) in Ecosystem and landscape conservation area of Korea. 


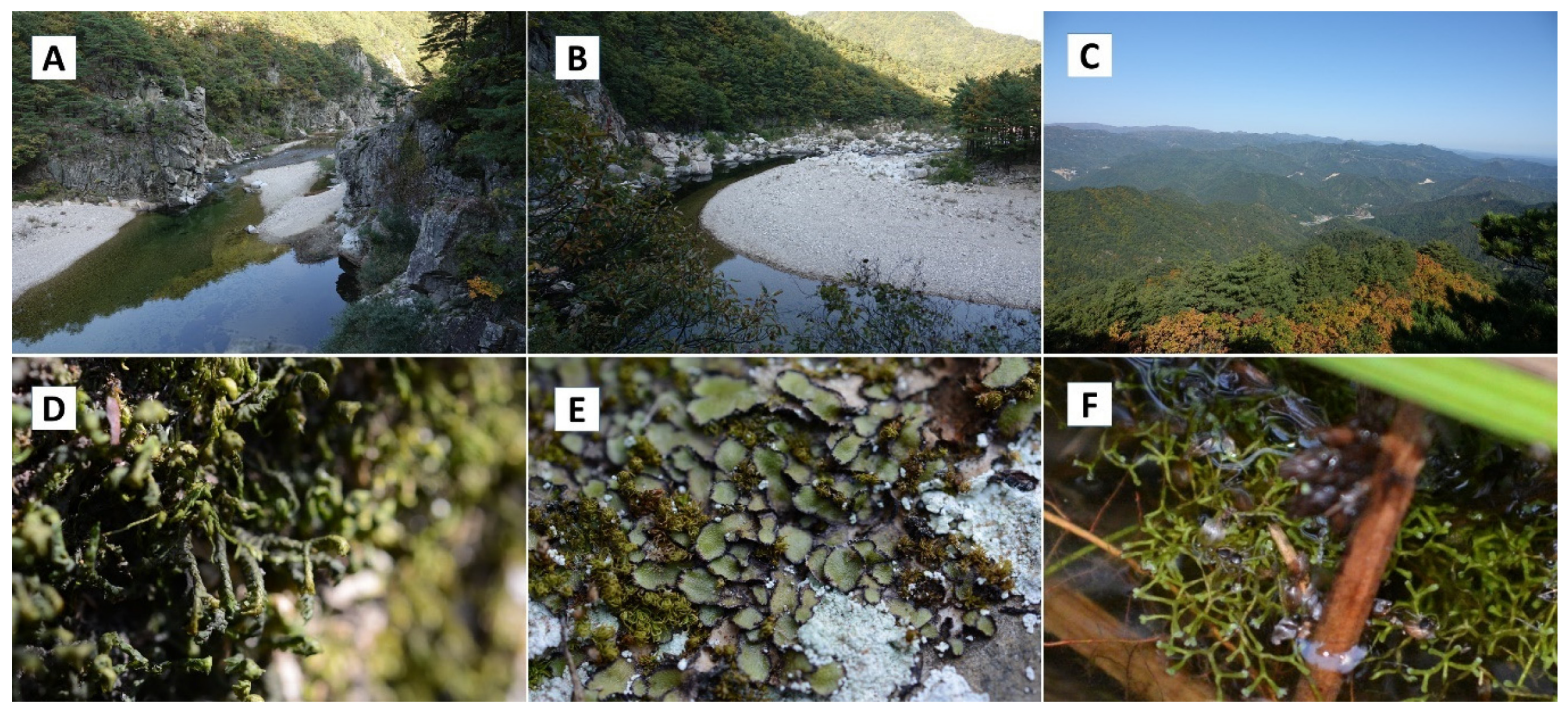

Fig. 2. Landscapes and remarkable bryophytes of Wangpicheon watershed (study area) in Ecosystem and landscape conservation area of Korea. A. Entrance of Wangpicheon. B. Middie part of Wangpicheon. C. Mountanins of Wangpicheon. D. Porella stephaniana (C. Massal.) S. Hatt. E. Plagiochasma japonicum (Steph.) C. Massal. F. Riccia fluitans L.

Table 1. The dates and routes in this study.

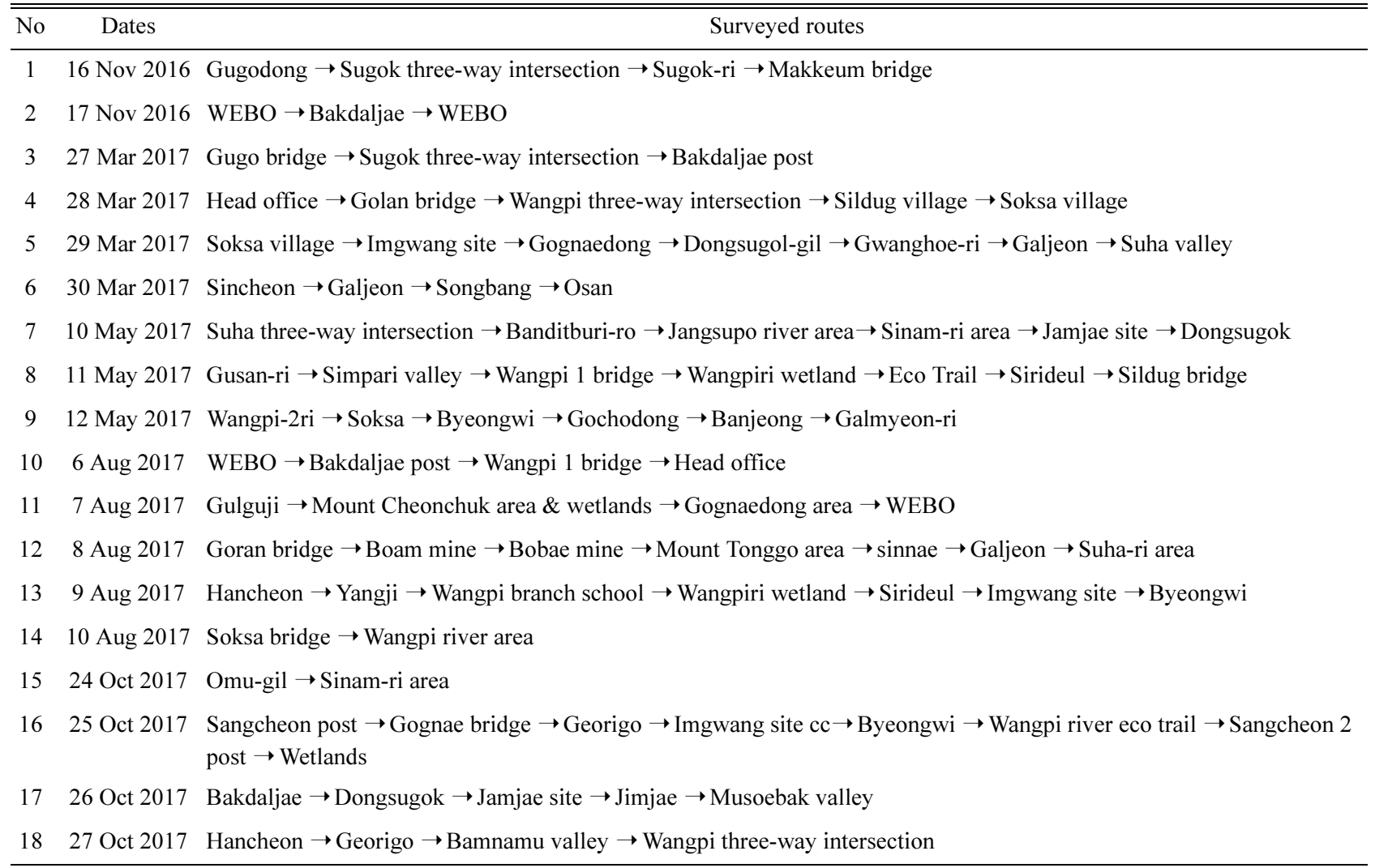

WEBO, Wangpicheon Environmental Branch Office.

(939 m)으로 둘러싸여 있다(Figs. 1, 2A-C). 왕피천 생태·경 관보전지역의 전체 면적 $\left(102,841 \mathrm{~km}^{2}\right)$ 중 산림은 $98.91 \mathrm{~km}^{2}$ 로 $96.2 \%$ 이고, 경작지가 $1.54 \mathrm{~km}^{2}$ 로 $1.5 \%$ 이며, 그 외에는
하천, 주거지, 도로 등이다(Anonymous, 2007). 환경부에서 는 「자연환경보전법」제 12 조를 근거로 다양한 생태계 및 우수한 자연경관과 멸종위기종(critically endangered, CR) 
및 희귀야생 동·식물 등 높은 생물다양성에 대하여 보전 할 필요가 있는 지역으로 판단하여 2005년 10 월 14 일에 생 태·경관보전지역으로 지정·고시하였다. 이곳의 주요 산림 식생은 소나무, 신갈나무, 굴참나무림이며, 일부는 식재 된 일본잎갈나무와 잣나무림 등이다. 왕피천유역 일대의 산림은 경사가 심하고 건조하여 대부분 소나무와 굴참나 무림이며, 일부 계곡부에서는 혼효림, 산지습지에는 진퍼 리새, 하천 및 배후습지에는 버드나무와 달뿌리풀 등이 주된 우점종으로 나타난다.

\section{조사일정}

조사지역 내에 분포하는 비관속식물의 선태식물상과 관속식물상을 파악하기 위하여 3계절(봄, 여름, 가을) 이상 조사시기를 선정, 봄은 이른 봄과 늦봄으로 구분하였고, 선 태류의 경우 주로 포자체 형성시기(봄, 가을)를 고려하여 조사를 수행하였다. 조사기간은 2016년 11월부터 2017년 10 월까지 총 18 회 이상 현지조사를 실시하였다(Table 1).

\section{조사방법}

조사지역에 대한 식물상 조사는 제4차 전국자연환경조 사 식물상 조사지침(National Institute of Ecology, 2014)에 의거하여 수행하였다. 선태식물은 현장에서 채집한 식물 체를 자체 제작한 표본봉투 $(21.5 \times 29.7 \mathrm{~cm})$ 에 담았으며, 표 본정보들을 기록하였다. 야외조사를 통해 채집한 관속식 물 및 선태식물은 증거표본으로 제작하고, 국립생태원 (NIE)과 대전대학교 표본관(TUT)에 보관하였다. 식물의 동정은 Lee (2003a, 2003b), Lee (2006), Park (2009) 등의 도 감을 활용하였으며, 과별 배열은 한국속식물지(Park, 2007)를 따랐고, 속이하의 배열은 알파벳순으로 정리하였 다. 학명의 채택과 분류군의 배열은 국가생물종목록집 (National Institute of Biological Resources, 2019)을 이용하였 다. 선태식물의 동정은 한국동식물도감 선태식물편(Choe,
1980), 북한식물지(Kim and Hwang, 1991), 일본식물지 (Noguchi, 1987, 1988, 1989, 1991, 1994), 중국식물지(Wu et al., 2002, 2005, 2011) 등 국내·외 문헌을 참고하였으며, 분 류체계는 Goffinet et al. (2009), Crandall-Stotler et al. (2009) 을 따랐다. 본 조사에서 밝혀진 식물목록을 토대로 식물 구계학적 특정종(Kim et al., 2018), 한국 고유식물(Kim and Park, 2013; Nam et al., 2018), 국가적색목록(National Institute of Biological Resources, 2012), 희귀식물목록(Korea Forest Service, 2018), 한반도 기후변화 적응 대상식물 300 (Oh et al., 2010), 생태계교란식물 및 귀화식물(Park, 2009; Lee et al., 2011; Ministry of Environment, 2019) 목록 기준에 근거하여 분석하였으며, 최근에 보고된 종들은 논문과 문 헌을 참고하였다.

\section{결 과}

\section{육상식물의 분포 및 생육현황}

왕피천유역의 생태·경관보전지역에 생육하고 있는 육 상식물(선태류 및 관속식물)은 확증표본을 근거로 전체 164 과 455속 698종 10 아종 47변종 3품종으로 총 758 분류 군이 생육하고 있음을 확인하였다(Table 2, Appendix 1). 이 중, 선태식물류는 46과 88 속 120 종 2 변종, 총 122 분류군이 확인되어 한반도 전체 925분류군(National Biodiversity Center, 2019)의 $13.2 \%$ 로 나타났다. 그리고 관속식물은 118 과 367 속 578 종 10 아종 45 변종 3 품종, 총 636 분류군으로 집계되어 한반도 전체 4,552분류군(National Biodiversity Center, 2019)의 $14 \%$ 에 해당하는 식물이 왕피천유역의 식 물상을 이루고 있다.

조사지역은 Table 4의 식물구계학적 특정식물에서 보는 바와 같이 거의 대부분 북방계식물이 분포하는 것으로 나 타나 식물구계학적으로 Lee and Yim (1978)의 중부아구에 포함된다고 할 수 있다.

Table 2. The number of land plants distributed in the Wangpicheon area.

\begin{tabular}{lccccccc}
\hline \multicolumn{1}{c}{ Taxa / St. } & Fam. & Gen. & Sp. & Subsp. & Var. & For. & Total \\
\hline Bryophyta & 28 & 62 & 83 & - & 2 & - & 85 \\
Marchantiophyta & 16 & 24 & 35 & - & - & - & 35 \\
Anthocerophyta & 2 & 2 & 2 & - & - & - & 2 \\
Bryophytes Total & 46 & 88 & 120 & - & 2 & - & 122 \\
Pteridophyta & 15 & 21 & 43 & - & 1 & - & 44 \\
Gymnospermae & 3 & 5 & 7 & - & - & - & 7 \\
Angiospermae & 100 & 341 & 528 & 10 & 44 & 3 & 585 \\
$\quad$ Dicotyledons & 85 & 260 & 391 & 8 & 31 & 3 & 433 \\
Monocotyledons & 15 & 81 & 137 & 2 & 13 & - & 152 \\
Vascular Plnats Total & 118 & 367 & 578 & 10 & 45 & 3 & 636 \\
Plant Total & 164 & 455 & 698 & 10 & 47 & 3 & 758 \\
\hline
\end{tabular}




\section{선태식물의 기후학적 분포 특성}

선태식물의 기후학적 분포 특성을 파악하고자 4개 기 후대(한대, 냉대, 온대, 열대)를 기본으로 9개(한대, 한대냉대, 냉대, 냉대-온대, 온대, 온대-아열대, 아열대, 아열대열대, 전기후)로 구분한 Bakalin (2010)을 따라 분석하였다. 왕피천 생태경관 보전지역의 선태식물 기후학적 분포 특 성은 냉대-온대성 식물 35 종 $(28.7 \%)$ 이 가장 많이 분포하 며, 그 다음으로 온대성 식물 25종(20.5), 기후에 상관없이

Table 3. The latitude fractional composition in the Wangpicheon area.

\begin{tabular}{lcc}
\hline $\begin{array}{l}\text { Floristic elements } \\
\text { (latitudinal types) }\end{array}$ & Taxa & Ratio (\%) \\
\hline Arctic & 0 & 0 \\
Arctic-boreal & 3 & 2.5 \\
Boreal & 3 & 2.5 \\
Boreal-temperate & 35 & 28.7 \\
Temperate & 25 & 20.5 \\
Temperate-subtropical & 21 & 17.2 \\
Subtropical & 4 & 3.3 \\
Subtropical-tropical & 7 & 5.7 \\
Multi-zone & 16 & 19.7 \\
\hline \multicolumn{1}{c}{ Total } & 122 & 100 \\
\hline
\end{tabular}

전지역 분포하는 전기후성 식물 24종(19.7\%), 온대-아열 대성 식물 21종(17.2\%), 아열대-열대성 식물 7종(5.7) 순으 로 분포함이 밝혀졌다(Table 3). 빨간비늘이끼, 숲날개이 끼, 아기두끝벼슬이끼 등의 한대-냉대성 식물과, 가는물 우산대이끼, 패랭이우산이끼, 물비늘이끼 등의 냉대성 선 태식물이 왕피천 주변의 그늘지고 습한 바위 겉에 주로 분포하고 있다. 이런 결과는 선태식물도 관속식물과 같이 중구아구의 특성을 보여준다고 할 수 있다.

\section{관속식물의 식물구계학적 특정식물}

어느 특정 지역공간 내 식물상의 분포현황을 통해 자연 환경 우수성의 정도 및 비교 우·열세를 파악하고자 선정 된 식물구계학적 특정식물(Kim et al., 2018)은 총 113분류 군으로 왕피천의 관속식물 630 분류군 중, 약 $17.8 \%$ 를 차 지하며, 북방계 식물이 주를 이루고 있다. 환경변화에 쉽 게 도태될 수 있으며 지리적 가치가 높은 $\mathrm{V}$ 등급에는 큰잎 쓴풀이 있으며, IV등급에는 참우드풀, 꼬리진달래, 덕우 기름나물 등 6분류군, III등급은 산꽃고사리삼, 노랑갈퀴, 난사초 등 31 분류군이다. II등급은 부채괴불이끼, 백작약, 택사 등 38 분류군, I등급은 오갈피나무, 산조팝나무, 연복 초 등 37 분류군을 확인하였다(Table 4). 그 중, 식물구계학 적으로 가장 중요하게 취급되는 $\mathrm{V}-\mathrm{IV}$ 등급의 큰잎쓴풀은 강원 양양, 평창, 고성의 높은 산지와 경북 울진에 간헐적 으로 분포하는 북방계성 산지식물로 본 조사에서는 천축

Table 4. The list of the floristic target species investigated in the Wangpicheon area.

\begin{tabular}{llc}
\hline \hline \multicolumn{1}{c}{ Family names } & \multicolumn{1}{c}{ Scientific names/Korean names } & Grade \\
\hline Gentianaceae & Swertia wilfordii A. Kern. 큰잎쓴풀 & V \\
Woodsiaceae & Woodsia macrochlaena Kuhn 참우드풀 & IV \\
Ranunculaceae & Cimicifuga heracleifolia var. bifida Nakai 세잎승마 & IV \\
Ericaceae & Rhododendron micranthum Turcz. 꼬리진달래 & IV \\
Fabaceae & Wisteria floribunda (Willd.) DC. 등 & IV \\
Apiaceae & Sillaphyton podagraria (H. Boissieu) Pimenov. 덕우기름나물 & IV \\
Lentibulariaceae & Utricularia bifida L. 땅귀개 & IV \\
Ophioglossaceae & Botrychium japonicum (Prantl) Underw. 산꽃고사리삼 & III \\
Equisetaceae & Equisetum hyemale L. 속새 & III \\
Ranunculaceae & Clematis heracleifolia DC. 병조희풀 & III \\
Ranunculaceae & Eranthis stellata Maxim. 너도바람꽃 & III \\
Fumariaceae & Dicentra spectabilis (L.) Lem. 금낭화 & III \\
Ulmaceae & Celtis koraiensis Nakai 왕팽나무 & III \\
Betulaceae & Betula dahurica Pall. 물박달나무 & III \\
Betulaceae & Betula schmidtii Regel 박달나무 & III \\
Clusiaceae & Triadenum japonicum (Blume) Makino 물고추나물 & III \\
Salicaceae & Salix siuzevii Seemen 참오굴잎버들 & III \\
Ericaceae & Vaccinium hirtum var. koreanum (Nakai) Kitam. 산앵도나무 & III \\
\hline
\end{tabular}


Table 4. Continued.

\begin{tabular}{|c|c|c|}
\hline Family names & $\begin{array}{l}\text { Scientific names/Korean names } \\
\end{array}$ & Grade \\
\hline Primulaceae & Lysimachia davurica Ledeb. 좁쌀풀 & III \\
\hline Rosaceae & Prunus mandshurica var. glabra Nakai 개살구나무 & III \\
\hline Rosaceae & Sorbaria sorbifolia var. stellipila Maxim. 쉬땅나무 & III \\
\hline Rosaceae & Spiraea chamaedryfolia L. 인가목조팝나무 & III \\
\hline Rosaceae & Spiraea chinensis Maxim. 당조팝나무 & III \\
\hline Rosaceae & Spiraea fritschiana C. K. Schneid. 참조팝나무 & III \\
\hline Fabaceae & Vicia chosenensis Ohwi 노랑갈퀴 & III \\
\hline Euphorbiaceae & Euphorbia ebracteolata Hayata 붉은대극 & III \\
\hline Aceraceae & Acer palmatum Thunb. 단풍나무 & III \\
\hline Aceraceae & Acer triflorum Kom. 복자기 & III \\
\hline Apiaceae & Angelica gigas Nakai 당귀 & III \\
\hline Asclepiadaceae & Cynanchum nipponicum Matsum. 덩굴박주가리 & III \\
\hline Solanaceae & Scopolia japonica Maxim. 미치광이풀 & III \\
\hline Scrophulariaceae & Melampyrum setaceum (Palib.) Nakai 애기며느리밥풀 & III \\
\hline Scrophulariaceae & Pseudolysimachion dahuricum (Steven) Holub 구와꼬리풀 & III \\
\hline Linnaeaceae & Zabelia biflora (Turcz.) Makino 털 댕강나무 & III \\
\hline Dipsacaceae & Dipsacus japonicus Miq. 산토끼꽃 & III \\
\hline Asteraceae & Aster maackii Regel 좀개미취 & III \\
\hline Araceae & Symplocarpus nipponicus Makino 애기앉은부채 & III \\
\hline Cyperaceae & Carex lasiolepis Franch. 난사초 & III \\
\hline Osmundaceae & Osmunda cinnamomea L. 뀡고비 & II \\
\hline Hymenophyllaceae & Crepidomanes minutum (Blume) K. Iwats. 부채괴불이끼 & II \\
\hline Aspleniaceae & Asplenium castaneo-viride Baker 거미꼬리고사리 & II \\
\hline Woodsiaceae & Woodsia subcordata Turcz. 산우드풀 & II \\
\hline Onocleaceae & Matteuccia struthiopteris (L.) Tod. 청나래고사리 & II \\
\hline Polypodiaceae & Pyrrosia petiolosa (H. Christ) Ching 애기석위 & II \\
\hline Pinaceae & Abies holophylla Maxim. 전나무 & II \\
\hline Pinaceae & Pinus koraiensis Siebold \& Zucc. 잣나무 & II \\
\hline Magnoliaceae & Magnolia sieboldii K. Koch 함박꽃나무 & II \\
\hline Schisandraceae & Schisandra chinensis (Turcz.) Baill. 오미자 & II \\
\hline Betulaceae & Alnus japonica (Thunb.) Steud. 오리나무 & II \\
\hline Caryophyllaceae & Lychnis cognata Maxim. 동자꽃 & II \\
\hline Paeoniaceae & Paeonia japonica (Makino) Miyabe \& Takeda 백작약 & II \\
\hline Tiliaceae & Tilia mandshurica Rupr. \& Maxim. 찰피나무 & II \\
\hline Tiliaceae & Tilia rufa (Nakai) Nakai 털피나무 & II \\
\hline Tiliaceae & Tilia taquetii C. K. Schneid. 뽕잎피나무 & II \\
\hline Droseraceae & Drosera rotundifolia $\mathrm{L}$ 끈끈이주걱 & II \\
\hline Violaceae & Viola orientalis (Maxim.) W. Becker 노랑제비꽃 & II \\
\hline Saxifragaceae & Mukdenia rossii (Oliv.) Koidz. 돌단풍 & II \\
\hline Rosaceae & Potentilla yokusaiana Makino 민눈양지꽃 & II \\
\hline
\end{tabular}


Table 4. Continued.

\begin{tabular}{|c|c|c|}
\hline Family names & Scientific names/Korean names & Grade \\
\hline Rosaceae & Spiraea salicifolia L. 꼬리조팝나무 & II \\
\hline Celastraceae & Tripterygium regelii Sprague \& Takeda 미역줄나무 & II \\
\hline Rutaceae & Phellodendron amurense Rupr. 황벽나무 & II \\
\hline Apiacea & Cymopterus melanotilingia (H. Boissieu) C. Y. Yoon 큰참나물 & II \\
\hline Conovolvulaceae & Calystegia soldanella (L.) Roem. \& Schult. 갯메꽃 & II \\
\hline Lamiaceae & Scutellaria dependens Maxim. 애기골무꽃 & II \\
\hline Rubiaceae & Rubia chinensis Regel \& Maack 큰꼭두서니 & II \\
\hline Diervillaceae & Weigela florida (Bunge) A. DC. 붉은병꽃나무 & II \\
\hline Asteraceae & Ligularia fischeri (Ledeb.) Turcz. 곰취 & II \\
\hline Alismataceae & Alisma canaliculatum A. Braun \& C. D. Bouché 택사 & II \\
\hline Alismataceae & Alisma orientale (Sam.) Juz. 질경이택사 & II \\
\hline Cyperaceae & Carex jaluensis Kom. 참삿갓사초 & II \\
\hline Cyperaceae & Carex pediformis var. pedunculata Maxim. 왕그늘사초 & II \\
\hline Cyperaceae & Carex planiculmis Kom. 그늘흰사초 & II \\
\hline Poaceae & Glyceria leptolepis Ohwi 왕미꾸리광이 & II \\
\hline Poaceae & Poa matsumurae Hack. 가는포아풀 & II \\
\hline Liliaceae & Heloniopsis koreana S. Fuse, N. S. Lee \& M. N. Tamura 처녀치마 & II \\
\hline Iridaceae & Iris ensata var. spontanea (Makino) Nakai 꽃창포 & II \\
\hline Pteridaceae & Cheilanthes argentea (S. G. Gmel.) Kunze 부싯깃고사리 & I \\
\hline Onocleaceae & Onoclea sensibilis L. 야산고비 & I \\
\hline Chloranthaceae & Chloranthus japonicus Siebold 홀아비꽃대 & I \\
\hline Ranunculaceae & Aconitum jaluense Kom. 투구꽃 & I \\
\hline Ranunculaceae & Clematis patens C. Morren \& Decne. 큰꽃으아리 & I \\
\hline Ranunculaceae & Hepatica asiatica Nakai 노루귀 & I \\
\hline Ulmaceae & Ulmus davidiana var. japonica (Rehder) Nakai 느릅나무 & I \\
\hline Urticaeae & Pilea japonica (Maxim.) Hand.-Mazz. 산물통이 & I \\
\hline Juglandaceae & Juglans mandshurica Maxim. 가래나무 & I \\
\hline Caryophyllaceae & Cucubalus baccifer var. japonicus Miq. 덩굴별꽃 & I \\
\hline Salicaceae & Salix chaenomeloides Kimura 왕버들 & I \\
\hline Brassicaceae & Sisymbrium luteum (Maxim.) O. E. Schulz 노란장대 & I \\
\hline Hydrangeaceae & Deutzia glabrata Kom. 물참대 & I \\
\hline Hydrangeaceae & Deutzia parviflora Bunge 말발도리 & I \\
\hline Hydrangeaceae & Deutzia uniflora Shirai 매화말발도리 & I \\
\hline Saxifragaceae & Chrysosplenium japonicum (Maxim.) Makino 산괭이눈 & I \\
\hline Rosaceae & Malus baccata (L.) Borkh. 야광나무 & I \\
\hline Rosaceae & Pyrus ussuriensis Maxim. 산돌배나무 & I \\
\hline Rosaceae & Rosa wichuraiana Crép. 돌가시나무 & I \\
\hline Rosaceae & Sanguisorba tenuifolia Link. 가는오이풀 & I \\
\hline Rosaceae & Spiraea blumei G. Don 산조팝나무 & I \\
\hline Fabaceae & Lespedeza maritima Nakai 해변싸리 & I \\
\hline
\end{tabular}


Table 4. Continued.

\begin{tabular}{|c|c|c|}
\hline Family names & Scientific names/Korean names & Grade \\
\hline Onagraceae & Circaea cordata Royle 쇠털이슬 & I \\
\hline Celastraceae & Euonymus maackii Rupr. 좁은잎참빗살나무 & I \\
\hline Euphorbiaceae & Euphorbia pekinensis Boiss. 대극 & I \\
\hline Rutaceae & Dictamnus dasycarpus Turcz. 백선 & I \\
\hline Araliaceae & Eleutherococcus sessiliflorus (Rupr. \& Maxim.) S. Y. Hu 오갈피나무 & I \\
\hline Asclepiadaceae & Cynanchum ascyrifolium (Franch. \& Sav.) Matsum. 민백미꽃 & I \\
\hline Asclepiadaceae & Tylophora floribunda Miq. 왜박주가리 & I \\
\hline Campanulaceae & Campanula punctata Lam. 초롱꽃 & I \\
\hline Caprifoliaceae & Lonicera maackii (Rupr.) Maxim. 괴불나무 & I \\
\hline Adoxaceae & Adoxa moschatellina L. 연복초 & I \\
\hline Asteraceae & Cirsium pendulum DC. 큰엉겅퀴 & I \\
\hline Alismataceae & Sagittaria aginashi Makino 보풀 & I \\
\hline Cyperaceae & Carex okamotoi Ohwi 지리대사초 & I \\
\hline Liliaceae & Asparagus oligoclonos Maxim. 방울비짜루 & I \\
\hline Liliaceae & Hosta capitata (Koidz.) Nakai 일월비비추 & I \\
\hline
\end{tabular}

산 임도의 가장자리를 따라 아주 드물게 생육하는 것을 확인하였다. 참우드풀은 강원과 경북 산지의 습한 바위틈 에 분포하는 것으로 알려져 있으며, 왕피천 일대에서도 통고산의 나출된 암반들 중 습한 장소에 산발적으로 자생 하는 것을 확인하였다. 꼬리진달래는 석회암 지표식물로 강원, 충북, 경북의 석회암지역의 반그늘진 바위지대나 건조한 산지 능선부 등지에 무리지어 생육하는 것으로 확 인되고 있으며, 왕피천에서도 주변 대부분의 산지 능선과 바위지대에 넓게 자생하고 특히 임도 주변 산지 가장자리 를 따라 생육하는 것을 확인하였다. 한편, 세잎승마는 우 리나라 식물구계 중 중부아구에만 분포하는 분류군으로 강원도·경상도·충청도에서만 발견되며, 왕피천 일대에서 는 산지사면부 그늘지고 습한 장소들에서 개체수준으로
생육하고 있었다. 최근 한국 고유속(Korean endemic genus) 으로 발표(Pimenov et al., 2016)된 덕우기름나물은 아래의 한반도 고유종에 설명한 바와 같다.

\section{한반도고유종}

왕피천 보호지역에서 생육하고 있는 한반도 고유식물 은 총 9 분류군으로 왕피천 전체 관속식물의 약 $1.4 \%$ 이다 (Table 5). 그 중, 한국의 대부분의 도감류에서 언급되지 않 을 정도로 그 실체가 잘 알려져 있지 않은 덕우기름나물이 통고산의 동사면부에 드물게 생육하고 있음을 확인하였다 (Fig. 3F). 덕우기름나물은 1969년 6월 7일 강원도의 덕우산 에서 지형준이 채집한 표본을 근거로 Kitagawa (1972)가 신 분류분군으로 발표하여 최근까지도 기름나물속의

Table 5. The list of the endemic plants investigated in the Wangpicheon area.

\begin{tabular}{ll}
\hline \hline \multicolumn{1}{c}{ Family names } & \multicolumn{1}{c}{ Scientific names/Korean names } \\
\hline Ranunculaceae & Cimicifuga heracleifolia var. bifida Nakai 세잎승마 \\
Ranunculaceae & Clematis trichotoma Nakai 할미밀망 \\
Ericaceae & Vaccinium hirtum var. koreanum (Nakai) Kitam. 산앵도나무 \\
Fabaceae & Lespedeza maritima Nakai 해변싸리 \\
Fabaceae & Vicia chosenensis Ohwi 노랑갈퀴 \\
Apiaceae & Sillaphyton podagraria (H. Boissieu) Pimenov. 덕우기름나물 \\
Scrophulariaceae & Paulownia coreana Uyeki 오동나무 \\
Asteraceae & Saussurea macrolepis (Nakai) Kitam. 각시서덜취 \\
Cyperaceae & Carex okamotoi Ohwi 지리대사초 \\
\hline
\end{tabular}



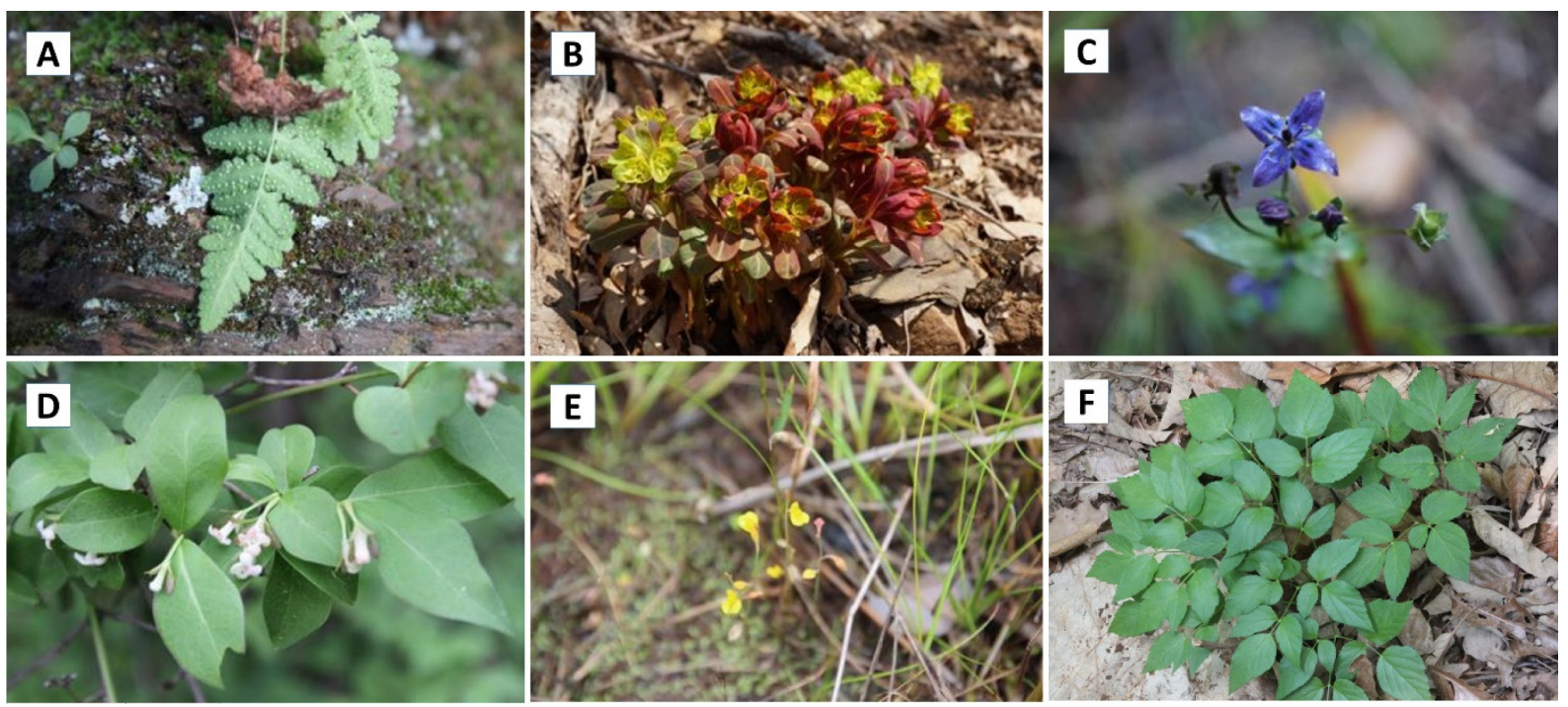

Fig. 3. Remarkable vascular plants of Wangpicheon watershed (study area) in ecosystem and landscape conservation area of Korea. A. Woodsia macrochlaena Kuhn. B. Euphorbia ebracteolata Hayata. C. Swertia wilfordii A. Kern. D. Zabelia biflora (Turcz.) Makino. E. Utricularia bifida L. F. Sillaphyton podagraria (H. Boissieu) Pimenov.

Table 6. The list of the rare plants in the Wangpicheon area.

\begin{tabular}{ccc}
\hline \hline Family names & Scientific names/Korean names & Grade \\
\hline Gentianaceae & Swertia wilfordii A. Kern. 큰잎쓴풀 & VU \\
Paeoniaceae & Paeonia japonica (Makino) Miyabe \& Takeda 백작약 & NT \\
\hline
\end{tabular}

VU, vulnerable; NT, near threatened.

Peucedanum insolens Kitag.로 인식(Lee, 1996; Kim and Park, 2013)하여 왔으며, 강원도의 석회암 지대에 국한하여 분포 하는 것으로 알려져 있다(Kim and Park, 2013). 그러나 이와 동일한 종으로 평가되는 식물이 이미 1901년 9월 3일 한국 의 중부지역 산지의 해발 $1,000 \mathrm{~m}$ 에서 Faurie에 의해 채집되 어 이를 근거로 Boissieu (1903)에 의해 Peucedanum podagraria H. Boissieu로 발표되었다. 최근 Pimenov et al. (2016)은 열매와 잎의 형태적 특성과 internal transcribed spacer 염기서열을 근거로 Sillaphyton $(=P$.) podagraria를 기 준종(type species)으로 하고 이에 P. insolens를 이명처리하여 한국 고유 단형속(endemic \& monotypic genus)인 Sillaphyton (덕우기름나물속)을 설정하였다. 덕우기름나물은 주로 석 회암지역의 산지에서 생육하는 것으로 알려지지만 종생태 적 특성은 거의 알려지지 않은 분류군으로 학술적인 종분 화 측면에서 매우 중요하다. 한편, 해변싸리는 1921년 전남 보길도에서 채집된 표본을 근거로 Nakai (1923)가 발표한 분류군으로 지리적으로 동해안의 강원, 서해안의 충남 이 남의 바닷가에 인접한 고도가 낮은 산지의 양지바른 돌밭 에 생육하지만 드물게 내륙지역에서도 생육하는 것으로 알려져 있다(Kim and Park, 2013; Nam et al., 2018). 본 조사에 서는 천축산 동남사면의 왕피천과 인접한 계곡 주변부에
무리지어 생육하고 있어 내륙에서는 거의 분포 최북단지 역으로 추정된다. 그리고 지리대사초는 주로 백두대간을 따라 남부에서 중부지역까지 활엽수림의 아래에 큰 무리 를 이루어 생육하는 분류군으로 왕피천 일대에서는 천축 산, 통고산의 신갈나무, 굴참나무 등으로 구성된 활엽수림 급경사지에 생육하고 있다. 그 외, 세잎승마, 산앵도나무, 노랑갈퀴, 각시서덜취 등은 산지 사면의 다소 반그늘진 곳 에, 할미밀망은 산자락의 양지바른 곳에, 오동나무는 비교 적 고도가 낮은 산지 사면에 생육한다.

\section{한국 멸종위기 야생동·식물 적색자료 관속식물}

왕피천 일대의 관속식물 분류군 중 적색목록 기준에 의 해 평가된 취약종( $\mathrm{VU}$, vulnerable)은 큰잎쓴풀, 준위협종 (NT, near threatened)은 백작약이 조사되었다(Table 6). 백작 약은 제주를 비롯하여 전국에 분포하나 주로 중부 이북 습한 전석지나 비옥한 토양에 흩어져 산생한다. 왕피천 일대에서도 천축산, 통고산, 대령산 등지 축축한 산사면 과 전석지에 1-3개체 정도씩 분포하고 있었다.

\section{기후변화 적응 대상식물}

왕피천 일대에서 기후 변화에 민감하게 반응할 수 있는 
Table 7. The list of northern and southern plants adaptable to climate change in the Wangpicheon area in Korea.

\begin{tabular}{llc}
\hline \hline \multicolumn{1}{c}{ Family names } & \multicolumn{1}{c}{ Scientific names/Korean names } & Source \\
\hline Equisetaceae & Equisetum hyemale L. 속새 & Northern plant \\
Pinaceae & Abies holophylla Maxim. 전나무 & Northern plant \\
Ranunculaceae & Eranthis stellata Maxim. 너도바람꽃 & Northern plant \\
Ericaceae & Rhododendron micranthum Turcz. 꼬리진달래 & Northern plant \\
Saxifragaceae & Mukdenia rossii (Oliv.) Koidz. 돌단풍 & Northern plant \\
Rosaceae & Spiraea salicifolia L. 꼬리조팝나무 & Northern plant \\
Euphorbiaceae & Euphorbia ebracteolata Hayata 붉은대극 & Northern plant \\
Aceraceae & Acer triflorum Kom. 복자기 & Northern plant \\
Gentianaceae & Gentiana triflora for. japonica (Kusn.) W. T. Lee \& W. K. Paik 과남풀 & Northern plant \\
Scrophulariaceae & Melampyrum setaceum (Palib.) Nakai 애기며느리밥풀 & Northern plant \\
Linnaeaceae & Zabelia biflora (Turcz.) Makino 털댕강나무 & Northern plant \\
Dipsacaceae & Dipsacus japonicus Miq. 산토끼꽃 & Northern plant \\
Asteraceae & Cirsium pendulum DC. 큰엉겅퀴 & Northern plant \\
Araceae & Symplocarpus nipponicus Makino 애기앉은부채 & Northern plant \\
Solanaceae & Scopolia japonica Maxim. 미치광이풀 & Southern plant \\
\hline
\end{tabular}

대상식물(Oh et al., 2010)은 거의 대부분 북방계식물로 산 토끼꽃, 털댕강나무 등 총 15 분류군을 확인하였으며, 왕 피천 전체 630 분류군의 약 $2.4 \%$ 에 해당한다(Table 7 , Fig. 3D). 이 중 산토끼꽃은 중국, 일본, 한국에만 분포하며 우 리나라에서도 서쪽 석회암지대인 강원, 경북 및 충북의 일부지역에 한정되어 자생하는 것으로 알려져 있다. 왕피 천 일대에서는 통고산 동쪽사면 동수골로 햇빛이 잘 드 는 계곡 주변에 생육하는 것을 확인하였다. 붉은대극은 한국, 일본 등 동아시아에 분포하며, 우리나라에서는 중 부 및 남부 산지 사면과 계곡부에 드물게 생육하는 것으 로 알려져 있다. 본 조사에서는 통고산 동쪽으로 급경사 지와 왕피천으로 연결되는 동수골 평지에 대규모 군락지 를 확인하였다. 남방계식물로는 미치광이풀 1 분류군이 통고산 동사면 계곡 주변 부식질이 많은 토양에서 군락을 이루어 생육하는 것을 확인하였다. 미치광이풀은 제주도, 경남, 전남을 제외한 지역과 북한지역에 주로 분포하는 것으로 알려져 북방계식물로 계속 보는 견해도 있으며 (Kim et al., 2018), 세계적으로 남아메리카(Tu et al., 2010), 일본 혼슈 남쪽에 분포하여 남방계식물로 보는 견해(Oh et al., 2010)도 있다.

\section{귀화식물 및 생태계교란식물}

조사지역 일대의 귀화식물은 46 분류군으로 왕피천 전 체 분류군의 $7.2 \%$ (귀화율)이며, 이 중 국화과는 20 분류군 으로 조사된 귀화식물 중 $43.5 \%$ 에 해당하여 가장 높은 비 율을 나타냈다(Table 8). 기존 왕피천 정밀조사에서는 42 분류군(Hyeon et al., 2012), 18분류군(Park and Lee, 2008)을
Table 8. The list of the naturalized plants investigated in the Wangpicheon area.

\begin{tabular}{ll}
\hline \hline Family names & \multicolumn{1}{c}{ Scientific names/Korean names } \\
\hline Phytolaccaceae & Phytolacca americana L. 미국자리공 \\
Chenopodiaceae & Chenopodium album L. 흰명아주 \\
Chenopodiaceae & Chenopodium ambrosioides L. 양명아주 \\
Chenopodiaceae & Chenopodium ficifolium Sm. 좀명아주 \\
Amaranthaceae & Amaranthus lividus L. 개비름 \\
Amaranthaceae & Amaranthus retroflexus L. 털비름 \\
Caryophyllaceae & Silene armeria L. 끈끈이대나물 \\
Polygonaceae & Rumex acetosella L. 애기수영 \\
Fabaceae & Amorpha fruticosa L. 족제비싸리 \\
Fabaceae & Robinia pseudoacacia L. 아까시나무 \\
Fabaceae & Trifolium repens L. 토끼풀 \\
Lythraceae & Ammannia coccinea Rottb. 미국좀부처꽃 \\
Onagraceae & Oenothera odorata Jacq. 달맞이꽃 \\
Euphorbiaceae & Euphorbia maculata L. 큰땅빈대 \\
Euphorbiaceae & Euphorbia supina Raf. 애기땅빈대 \\
Simaroubaceae & Ailanthus altissima (Mill.) Swingle 가중나무 \\
Conovolvulaceae & Cuscuta pentagona Engelm. 미국실새삼 \\
Conovolvulaceae & Ipomoea purpurea (L.) Roth 둥근잎나팔꽃 \\
Scrophulariaceae & Veronica arvensis L. 선개불알풀 \\
Scrophulariaceae & Veronica persica Poir. 큰개불알풀 \\
Asteraceae & Ambrosia artemisiifolia L. 돼지풀 \\
\hline
\end{tabular}


Table 8. Continued.

\begin{tabular}{ll}
\hline \hline Family names & \multicolumn{1}{c}{ Scientific names/Korean names } \\
\hline Asteraceae & Aster pilosus L. 미국쑥부쟁이 \\
Asteraceae & Bidens frondosa L. 미국가막사리 \\
Asteraceae & Carduus crispus L. 지느러미엉겅퀴 \\
Asteraceae & Coreopsis alternifolia L. 나래가막사리 \\
Asteraceae & Conyza canadensis (L.) Cronquist 망초 \\
Asteraceae & Coreopsis lanceolata L. 큰금계국 \\
Asteraceae & Cosmos bipinnatus Cav. 코스모스 \\
Asteraceae & Erechtites hieracifolia (L.) DC. 붉은서나물 \\
Asteraceae & Erigeron annuas (L.) Pers. 개망초 \\
Asteraceae & Galinsoga parviflora Cav. 별꽃아재비 \\
Asteraceae & Galinsoga quaderiradiata Ruiz \& Pav. 털별꽃아재비 \\
Asteraceae & Helianthus tuberosus L. 뚱딴지 \\
Asteraceae & Lactuca scariola L. 가시상치 \\
Asteraceae & Rudbeckia hirta var. pulcherrima Farw. 원추천인국 \\
Asteraceae & Senecio vulgaris L. 개쑥갓 \\
Asteraceae & Sonchus asper (L.) Hill. 큰방가지똥 \\
Asteraceae & Tagetes minuta L. 만수국아재비 \\
Asteraceae & Taraxacum officinale F. H. Wigg. 서양민들레 \\
Asteraceae & Xanthium italicum Moretti 가시도꼬마리 \\
Commelinaceae & Tradescantia ohioensis Raf. 자주달개비 \\
Poaceae & Bromus tectorum L. 털빕새귀리 \\
Poaceae & Dactylis glomerata L. 오리새 \\
\hline Poaceae & Eragrostis curvula (Schrad.) Nees 능수참새그령 \\
\hline
\end{tabular}

Table 9. The list of the ecosystem disturbing plants investigated in the Wangpicheon area.

\begin{tabular}{ll}
\hline \hline \multicolumn{1}{c}{ Family names } & \multicolumn{1}{c}{ Scientific names/Korean names } \\
\hline Cannabaceae & Humulus japonicus Siebold \& Zucc. 환삼덩굴 \\
Polygonaceae & Rumex acetosella L. 애기수영 \\
Asteraceae & Ambrosia artemisiifolia L. 돼지풀 \\
Asteraceae & Aster pilosus L. 미국쑥부쟁이 \\
Asteraceae & Lactuca scariola L. 가시상치 \\
\hline
\end{tabular}

확인하였으며, 귀화율은 $6.8 \%, 1.8 \%$ 로 본 결과보다 다소 낮게 나타났다. 왕피천 인근 지역에서는 $\mathrm{Oh}$ and Shin (2006)이 53 분류군(8.2\%)으로 보고하여 본 조사보다 다소 높게 나타났다. 환경부 지정 생태계교란생물은 3 번의 왕 피천 정밀조사동안 2008년에 돼지풀 1종(Park and Lee, 2008), 2012년에 돼지풀과 애기수영 2종(Hyeon et al.,
2012), 2017년에는 5종(돼지풀, 애기수영, 미국쑥부쟁이, 가시상치, 환삼덩굴)으로 분류군 수가 늘어나고 있다 (Table 9). 지속적으로 발견되고 있는 돼지풀은 통고산 임 도, 미국쑥부쟁이는 남쪽 수하계곡 등 도로 주변, 가시상 치는 민가 주변에서 발견되었으나 이들 모두 협소한 지역 에 비교적 적은 개체 수가 확인되었다. 반면, 애기수영의 경우 왕피천 내 민가, 경작지, 임도와 도로 가장자리 등 다 양한 지역에서 군락을 이루고 있는 것으로 나타났다. 훼 손된 곳이나 도로 등 양지에 흔하게 생육하며 주변 식물 의 생육을 방해하던 환삼덩굴은 왕피천에서도 전역에 걸 쳐 분포하고 있으며, 최근 생태계교란생물로 지정(2019. 7. 26)되어 방제 등의 조치를 할 수 있게 되었다.

\section{고 찰}

일반적으로 지금까지의 육상의 식물상 조사는 대부분 관속식물에 국한되거나 예외적인 경우에 별개로 선태식 물만을 대상으로 수행되어 왔으나 본 연구에서는 같은 지역에서 분류학적으로 특성이 크게 다른 두개의 큰 식 물군, 즉 육상식물군 조사를 동일한 시기에 실시한 바, 그 의미가 크다. 보통 이끼라 부르는 선태식물류는 각 분류 군의 분포도 중요하지만 이들이 주로 육상의 습한 곳에서 생육하기 때문에 생육지의 환경 변화에 매우 민감하게 반 응할 수 있는 분류군으로 관속식물의 분포 및 생육 환경 이나 습성과도 밀접한 관계가 있을 것으로 예상된다. 따 라서 향후, 생태적으로 특이 환경을 갖는 지역 또는 산지 의 식물상 조사를 선태식물과 관속식물의 생태학적 생육 습성의 역학 관계를 고려하여 동시에 수행한다면, 각각 서로 다른 식물 다양성의 특성 분석과 동시에 이들 생태 의 역학적인 관계 또는 서로의 연관된 변화 양상을 추적 하는 데, 중요한 과학적 이슈가 될 수 있다고 판단된다.

본 조사에서 확인된 육상식물은 총 758 분류군(관속식 물 636분류군, 선태식물 122분류군)으로 2008년 정밀조사 457분류군(Park and Lee, 2008)과 2012년 정밀조사 613분류 군(Hyeon et al., 2012)에 비해 264분류군과 108분류군의 차 이를 보였는데, 이는 기존에 선태식물이 조사된 바가 없 기 때문인 것으로 보인다. 한편, 과거 보고서 $(2008,2012)$ 에서 언급된 관속식물의 가지괭이눈, 도깨비부채, 사창분 취, 왕느릅나무 등 200 여 분류군을 확인하지 못하였고, 산 우드풀, 산꽃고사리삼, 거미꼬리고사리, 우단일엽, 인가 목조팝나무, 붉은대극, 택사, 애기앉은부채, 좀네모골, 송 이고랭이 등 170 여 분류군을 새로이 확인하였다. 이는 기 존의 조사경로 또는 조사시기가 다르기 때문인 것으로 판 단됨과 동시에 과거 일부 오동정된 분류군을 비롯하여 딸 기 등과 같은 재배식물까지 포함한 차이로 보였다. 2008 년부터 현재까지 약 10 년 동안 왕피천 정밀조사에서 보고 된 관속식물은 893 분류군으로 이에 선태식물을 포함하면 약 980 여 분류군이 보전지역에 분포하는 것으로 파악된 
다. 이는 왕피천 보전지역 주변, 즉 불영사계곡 일대, 통고 산 일대 등의 식물상이 560-641분류군(Lee et al., 1976; Kim and Do, 2001; Chung and Kim, 2003; Oh and Shin, 2006) 인 점을 감안하면 보다 다양한 분류군이 생육하는 것으로 받아들여 진다. 그리고 과거의 정밀조사를 종합정리한 동 강유역의 생태·경관 지역의 831 분류군(Kim and Chae, 2019)보다 높은 결과였다. 이는 일부 관속식물의 차이와 더불어 선태식물의 조사가 동시에 이루어졌기 때문에 가 능한 결과였다.

국내 환경부 지정 생태·경관보전지역 정밀조사 기간 (2014-2018) 내에 밝혀진 분류군은 130-619분류군 정도로 왕피천의 육상식물상은 확증표본을 근거로 관속식물만 으로도 636 분류군이 밝혀져 정밀조사 중 가장 많은 분류 군이 확인되었고, 선태식물상은 조사가 처음으로 수행되 었다. 관속식물상을 근거로 자연의 우수성과 환경을 평가 하는데 주로 이용되는 식물구계학적 특정식물은 큰잎쓴 풀을 비롯하여 총 113 분류군이 밝혀져 왕피천 일대의 환 경이 양호하고 다양성이 높다고 평가할 수 있다. 왕피천 유역은 중부 산악지역(Kong, 2007)으로 Table 4과 6에서 보 는 바와 같이 식물구계학적으로 대부분 북방계식물이 우 세하게 분포하는 중부아구 지역(Lee and Yim, 1978)에 포 함된다. 따라서 향후 기후변화에 취약할 수 있으므로 큰잎 쓴풀, 덕우기름나물 등을 비롯한 일부 종들은 현지 내·외 보존 방안을 마련하고, 추후 산림복원 또는 종 복원 시 활 용할 수 있는 전략적인 대책이 필요할 것으로 예상된다.

왕피천 보전지역 내에 분포하는 주요 관속식물 중, 통고 산 동사면부에 드물게 생육하는 덕우기름나물은 최근에 Pimenov et al. (2016)에 의해 덕우기름나물을 기준종으로 하여 한반도 고유 단형속으로 발표되었다. 결과적으로 덕 우기름나물속은 다른 한반도산 고유속인 제주고사리삼 속, 모데미풀속, 개느삼속, 미선나무속, 금강초롱꽃속과 더불어 생물학 및 진화적으로 매우 중요한 식물 분류군으 로 평가할 수 있다. 그러나 이들은 분류를 위한 일부 표징 형질(diagnostic character)의 특성과 강원도 정선, 영월과 같은 지역의 석회암지대에 분포한다는 정보만 알려질 뿐, 현재까지 이들의 국내 분포역 및 현황, 종생태를 비롯하 여 생물학적 특성은 잘 알려져 있지 않다. 따라서 왕피천 유역 일대의 생육하는 개체들은 보전가치가 매우 높다고 평가할 수 있다. 본 조사에서 처음 발견된 붉은대극의 자 생지는 2 만 $\mathrm{m}^{2}$ 정도이며, 왕피천 유역일대에 1,000 개체 이 상이 분포하고 있을 것으로 보인다(Fig. $3 \mathrm{~B}$ ). 이른 봄에 개 화하여 붉은색을 띠다가 점차 연녹색으로 변하는 특성을 갖고 있으며 국내 최대 군락지로 예상되는 만큼 왕피천을 대표하는 소나무와 더불어 보전가치가 높다고 평가할 수 있다. 그리고 바위 틈이나 겉에 생육하는 참우드풀도 처 음 확인하였으며 통고산 일대에서 소수의 개체만 발견되 어 보호할 필요가 있다(Fig. 3A). 식물구계학적 $\mathrm{V}$ 등급 및 적색목록집의 $\mathrm{VU}$ 그리고 산림청의 희귀식물의 $\mathrm{CR}$ 의 범
주에도 속하는 큰잎쓴풀은 정밀조사 시마다 분포가 확인 되고 있지만 국내 분포가 제한적일 뿐만 아니라 이들의 자생지가 임도 또는 등산로 주변 등 나출된 지역으로 개 체수가 많지 않아 훼손 위험이 아주 높은 종으로 평가되 므로 일부 자생지에 대한 주기적인 모니터링과 현지내 보 전대책 및 관리가 필요할 것으로 판단되었다(Fig. $3 \mathrm{C}$ ). 그 리고 산토끼꽃은 강원, 경북 드물게 충북지역에 작거나 크게 무리지어 생육하는 데, 왕피천 일대에서는 그 개체 수가 적고 생육지가 동수골 마을 주변으로 훼손될 가능성 이 큰 것으로 예상된다.

산중 습지에 생육하는 땅귀개는 식물구계학적 IV등급 으로 주로 국내 중부이남의 물기가 있는 습한 곳에 제한 적으로 생육하는 벌레잡이 식물로 왕피천에서는 천축산 내의 습지에서만 이들이 생육하는 것을 확인하였다(Fig. $3 \mathrm{E})$. 비교적 전국적으로 분포하는 또다른 식충식물인 끈 끈이주걱은 습지와 늪 등지의 상층이 열린 장소 또는 $5 \mathrm{~cm}$ 내외의 최저수심을 유지하는 미세요철입지에만 생육하 는 분류군으로(Lee et al., 2013) 왕피천의 임도에 인접한 산 중 습지의 가장자리에서 확인되기도 하였다. 왕피천의 습 지들은 예전부터 육지화가 진행되고 있어 왕피천 내에서 분포가 제한적인 분류군들을 대상으로 현지내 보전대책 을 시급하게 마련하고 실행하여 장기적으로 그 효과를 모 니터링해야 할 것으로 예상된다. 그리고 경북을 비롯한 중부 이북 산지의 천변 주변과 습지에 무리지어 생육하는 속새는 왕피천 관리소 등을 비롯한 그 주변에서 발견이 되기도 하지만 왕피천 주변의 배후습지에 이들이 크게 무 리지어 생육하고 있다. 이 외에도 왕피천 일대의 습지에 서는 택사 및 보풀 등의 다양한 수생식물과 가는그물이끼, 물가침부리이끼, 물긴가지이끼 등과 같은 선태식물이 추 가 확인되고 있어, 습지 보전 고려사항 중 습지식물의 종 보존을 위한 관리 및 대책마련도 꼭 포함되어야 할 것으 로 여겨진다.

한편, 선태식물 중, 석회질 토양에 주로 생육하는 동강 세줄이끼, 버섯우산이끼, 산누운깃털이끼 등이 왕피천 계 곡 주변 바위 위에서 생육하는 것을 발견하였다(Fig. 2D, E). 동강세줄이끼는 영월, 정선의 동강 주변에서 한반도 미기록으로 발견된 이후, 그 이외 지역에서는 처음 발견 되는 것이다. 아기겉굵은이끼는 일본, 사할린 등지에, 국 내에서 강원, 충북, 제주 등에 분포하며, 주로 고도가 높은 지역의 나무 기부나 바위 또는 부식토 위에서 생육하는 것으로 알려져 있다(Noguchi, 1994). 이들은 왕피천 임도 주변의 부식토 위에서 생육하는 것을 확인하였으며, 임도 주변 사면이라 산사태와 같은 환경변화에 민감하여 보호 가 필요하다. 물긴가지이끼는 습지에 드물게 생육하는 분 류군으로 왕피천 유역 일대 상천제 2 초소 인근 습지에 대 규모로 자생하고 있다(Fig. 2F). 왕피천의 생육지는 국내 다른 생육지 보다 큰 규모의 자생지로 판단할 수 있어 왕 피천에서 보전가치가 높다고 평가할 수 있다. 
과거, 일부 문헌에서 법정 멸종위기 야생생물 $\Pi$ 급인 산 작약이 왕피천 유역에 생육한다고 언급하고 있지만 왕피 천 관리소의 자생지 자료와 내부에서 분석한 산작약의 잠 재적 가능 생육지들을 모두 조사, 검토해 본 결과 백작약만 발견되었다. 산작약은 화경이 경생엽보다 길게 신장하고 화사는 흰색으로 백작약과 쉽게 식별이 가능(Jeong, 2011) 하기에 기존에 알려진 자생지는 모두 백작약의 오동정으 로 판단되며, 왕피천은 대체로 건조한 생태적 환경으로 산 작약이 분포할 가능성은 거의 희박한 것으로 판단된다.

왕피천 보호지역에 생육하는 귀화식물 및 생태계교란 종의 종수와 귀화율은 인근 지역의 식물상 조사보다 낮은 결과를 보였다. 그러나 5년 주기의 정밀조사 기간에 따른 식물 변화상 분석에서는 10 년 동안 이들의 개체 및 분포 지가 넓어진 것으로 나타나 향후 이에 대한 관리대책이 필요할 것으로 예상된다.

왕피천 유역 일대에는 $1,000 \mathrm{~m}$ 이상의 아고산지와 석회 암지대, 산지계곡, 산지습지, 묵논습지, 오래된 침식·퇴적 하천지형, 전석지, 동굴, 초지, 농경지, 급경사지 등과 바다 와 인접한 지정학적 위치로 야생 동·식물들이 서식할 수 있는 다양한 생태환경을 가지고 있다. 특히 천축산 일대 의 산중 습지들과 한천 및 독거리 일대의 묵논습지들은 많은 생물들의 서식처이자 생태계 연결다리 역할을 하고, 일부 희귀식물들에게는 피난처가 될 수도 있기에 동·식물 상이 높은 몇몇 지역들과 큰잎쓴풀, 붉은대극, 참우드풀, 덕우기름나물 등의 주요 관리가 필요한 식물들은 실질적 인 모니터링과 사후관리가 필요하다.

ORCID: Seung Hyuk LEE https://orcid.org/0000-0001-55386279; Jin Kap AHN https://orcid.org/0000-0002-3843-028X; Seung Jin PARK https://orcid.org/0000-0002-7967-8361; Chul Hwan KIM https://orcid.org/0000-0003-4894-0651; Seung Se CHOI https://orcid.org/0000-0002-3332-5544

\section{Acknowledgments}

This work was supported by a grant from the 5th National Ecosystem Survey and the investigation of Ecosystem and Landscape Conservation Area of National Institute of Ecology (NIE), funded by the Ministry of Environment (MOE) of the Republic of Korea (NIE-A-2020-01).

\section{Conflict of Interest}

The authors declare that there are no conflicts of interest.

\section{Literature Cited}

Ahn, J. K., S. H. Lee, S. J. Park and S. S. Choi. 2017. The flora. In
The Report of Detailed Investigation in Ecosystem and Landscape Conservation Area of Wangpicheon Watershed. National Institute of Ecology (ed.), National Institute of Ecology, Seocheon. Pp. 147-200. (in Korean)

Anonymous. 2007. The Basic Management Plan of in Ecosystem and Landscape Conservation Area of Wangpicheon Watershed. Daegu Regional Environmental Office, Daegu, 66 pp. (in Korean)

National Institute of Biological Resources. 2012. Red Data Book of Endangered Vascular Plants in Korea. Econature, Seoul, 390 pp. (in Korean)

National Institute of Ecology. 2014. A guide to the 4rd national natural environment research. National Institute of Ecology, Seocheon, 486 pp. (in Korean)

Bakalin, V. A. 2010. Hepaticae of the Kuril Islands (Northwestern Pacific): a transoceanic route from Circumboreal to East Asian flora. Annales Botanici Fennici 47: 81-105.

Boissieu, H. 1903. Les Ombellifeeres de Coreee d'apreles collections de M. l'abbe Faurie. Bulletin de l'Herbier Boissier Series 2, 11: 953-958.

Choe, D. M. 1980. Illustrated Flora and Fauna of Korea. Vol. 24. Musci-Hepaticae. Ministry of Education, Seoul, 790 pp. (in Korean)

Chung, K. Y. and M. K. Kim. 2003. The Report of Natural Ecosystem Survey: Flora Part. Ministry of Enviornment, Sejong. Pp. 25-31. (in Korean)

Crandall-Stotler, B., R. E. Stotler and D. G. Long. 2009. Morphology and classification of the Marchantiophyta. In Bryophyte Biology. Goffinet, B. \& A. J. Shaw (eds.), Cambridge University Press, Cambridge. Pp. 1-54.

Goffinet, B., W. R. Buck and A. J. Shaw. 2009. Morphology and classification of the Bryophyta. In Bryophyte Biology. Goffinet, B. and A. J. Shaw (eds.), Cambridge University Press, Cambridge. Pp. 55-138.

Hyun, J. O., B. W. Han, W. B. Seo and B. C. Lee. 2012. The flora. In The Report of Nature Environmantal Detailed Investigation in Ecosystem and Landscape Conservation Area of Wangpicheon. National Institute of Environmental Research (ed.), National Institute of Environmental Research, Incheon. Pp. 73-115. (in Korean)

Jeong, H. J. 2011. A taxonomic study of the genus Paeonia in Korea. MS thesis, Jeonbuk National University, Jeonju, Korea, 45 pp. (in Korean)

Kang, J. Y. and S. J. Oh. 2017. The flora. In The Report of Detailed Investigation in Ecosystem and Landscape Conservation Area of Wangpicheon Watershed. National Institute of Ecology (ed.), National Institute of Ecology, Seocheon. Pp. 55-87. (in Korean) 
Kim, C. H. and J. H. Park. 2013. Endemic Species of Korea: Plantae. National Institute of Biological Resources, Incheon, 912 pp. (in Korean)

Kim, C. H., M. O. Moon, J. K. Ahn, I. C. Hwang, S. H. Lee and S. S. Choi. 2018. Floristic Target Species (FT Species) in Korea. National Institute of Ecology, Seocheon, 728 pp. (in Korean)

Kim, J. H. and J. H. Do. 2001. Flora of Mt. Janggun· 974.2 · Tonggo Cheonchuk (City of Bonghwa and Uljin) and nearby mountainous area. In 2nd National Ecosystem Survey. National Institute of Environmental Research (ed.), National Institute of Environmental Research, Incheon. Pp. 92-144. (in Korean)

Kim, Y. C. and Y. H. Chae. 2019. The flora. In The 2018 Report of Detailed Investigation in Ecosystem and Landscape Conservation Area: Donggang River. National Institute of Ecology (ed.), National Institute of Ecology, Seocheon. Pp. 195-269. (in Korean)

Kim, Y. H. and H. J. Hwang. 1991. Korean Spore Plant 8 (Hepaticae). Publiching House of Science on Encyclopodia, Pyongyang, 223 pp. (in Korean)

Kitagawa, M. 1972. Notulae fractae ob floram Asiae orientalis. 29. Journal of Japanese Botany 47: 353-357.

Kong, W. S. 2007. Biogeography of Korean Plants. Geobook, Seoul. Pp. 144-159. (in Korean)

Korea Meteorological Administration. 2018. Annual Report 2017. Korea Meteorological Administration, Seoul, 542 pp. (in Korean)

Korea Forest Service. 2018. Act on the creation and furtherance of arboretumsand gardens. Act No. 15397. Retrieved May 2, 2020, available from http://elaw.klri.re.kr

Lee, S. H, H. R. Kim, Y. S. Han, R. H. Jang, H. M. Jeong, J. K. Jeong and Y. H. You. 2013. Vegetation conservation and management for rare insectivorous plants in Mujechi wetland. Journal of Restoration Ecology 3: 33-42. (in Korean)

Lee, T. B. 2003a. Coloured Flora of Korea. Vol. I. Hyangmunsa, Seoul, 914 pp. (in Korean)

Lee, T. B. 2003b. Coloured Flora of Korea. Vol. II. Hyangmunsa, Seoul, 910 pp. (in Korean)

Lee, W.-T. and Y. J. Yim. 1978. Studies on the distribution of vascular plants in the Korean Peninsula. Korean Journal of Plant Taxonomy 8: 1-33. (in Korean)

Lee, Y. G., I. S. Yang, M. K. Park and J. W. Park. 1976. The report of comprehensive academic investigation research of Buryeongsa temple valley. Korean Association for Conservation of Nature 10: 33-56. (in Korean)

Lee, Y.-M., S.-H. Park, S.-Y. Jung, S.-H. Oh and J.-C. Yang. 2011. Study on the current status of naturalized plants in South Korea. Korean Journal Plnat Taxonomy 41: 87-101. (in
Korean)

Lee, Y. N. 1996. Umbelliferae. In Flora of Korea. 3rd ed., KyoHak Publishing Co., Seoul. Pp. 547-572. (in Korean)

Lee, Y. N. 2006. New Flora of Korea, Vol. I, II. KyoHak Publishing Co., Seoul. Vol. 1, 975 pp, Vol. 2, 885 pp. (in Korean)

Ministry of Environment. 2019. Notification No. 2019-185 of Ecosystem disturbing organism. Retrieved Nov. 5, 2019, available from http://www.me.go.kr.

Nam, G. H., B. Y. Lee, M. H. Kwak, C. K. Lim, C. H. Kim, K. D. Han, E. S. Go and B. G. Kim. 2018. Plantae. In Endemic Species of Korea (revised ed.). National Institute of Biological Resources, Incheon. Pp. 599-751.

National Biodiversity Center. 2019. Biodiversity Ststistics of Korea 2018. National Institute of Biological Resources, Incheon, 272 pp. (in Korean)

National Institute of Biological Resources. 2019. National Species List of Korea: Vascular Plants. Vol. 1. National Institute of Biological Resources, Incheon. Pp. 51-206. (in Korean)

Nakai, T. 1923. Notulae ad Plantas Japoniae et Coreae XXX. Botanical Magazine, Tokyo 37: 69-82. (in Japanese)

Noguchi, A. 1987. Illustrated Moss Flora of Japan 1. Daigaku Printing Co., Ltd., Hirisima. Pp. 1-242.

Noguchi, A. 1988. Illustrated Moss Flora of Japan 2. Daigaku Printing Co., Ltd., Hirisima. Pp. 243-491.

Noguchi, A. 1989. Illustrated Moss Flora of Japan 3. Daigaku Printing Co., Ltd., Hirisima. Pp. 493-742.

Noguchi, A. 1991. Illustrated Moss Flora of Japan 4. Daigaku Printing Co., Ltd., Hirisima. Pp. 743-1012.

Noguchi, A. 1994. Illustrated Moss Flora of Japan 5. Daigaku Printing Co., Ltd., Hirisima. Pp. 1013-1253.

Oh, B. U., D. G. Jo, S. C. Ko, B. H. Choi, W. K. Paik, G. Y. Chung, Y. M. Lee and C. G. Jang. 2010. 300 Target Plants Adaptable to Climate Change in the Korean Peninsula. Korea National Arboretum, Pocheon, 492 pp. (in Korean)

Oh, H.-K and H.-T. Shin. 2006. Vascular plants of the Bulyeong Valley in Uljin-gun, Gyeongbuk. Korean Journal of Environmental Biology 24: 359-367. (in Korean)

Park, C. W. 2007. The genera of vascular plants of Korea. Academy Publishing Co., Seoul, 1482 pp.

Park, J. H. and W. Lee. 2008. The flora. In The Report of Nature Environmantal Detailed Investigation in Ecosystem and Landscape Conservation Area of Wangpicheon. Daegu Regional Environmental Office (ed.), Daegu Regional Environmental Office, Daegu. Pp. 23-67. (in Korean)

Park, J. Y. and Y. K. Lee. 2017. The flora. In The Report of Detailed Investigation in Ecosystem and Landscape Conservation Area of Wangpicheon Watershed. National Institute of Ecology (ed.), National Institute of Ecology, Seocheon. Pp. 1- 
52. (in Korean)

Park, S. H. 2009. New Illustrations and Photographs of Naturalized Plant of Korea. Ilchokak Publishing, Seoul, 588 pp. (in Korean)

Pimenov, M. G., T. A. Ostroumova, G. V. Degtjareva and T. H. Samigullin. 2016. Sillaphyton, a new genus of the Umbelliferae, endemic to the Korean Peninsula. Botanica Pacifica 5: $31-41$.

Tu, T., S. Volis, M. D. Dillon, H. Sun and J. Wen. 2010. Dispersals of Hyoscyameae and Mandragoreae (Solanaceae) from the New World to Eurasia in the early Miocene and their biogeographic diversification within Eurasia. Molecular Phyloge- netics and Evolution 57: 1226-1237.

Wu, P.-C., M. R. Crosby and S. He. 2002. Moss Flora of China, Vol. 6. Hookeriaceae-Thuidiaceae. Science Press, Beijing and Missouri Botanical Garden Press, St. Louis, MO, 221 pp.

Wu, P.-C., M. R. Crosby and S. He. 2005. Moss Flora of China, Vol. 8. Sematophyllaceae-Polytrichaceae. Science Press, Beijing and Missouri Botanical Garden Press, St. Louis, MO, 366 pp.

Wu, P. C., M. R. Crosby and S. He. 2011. Moss Flora of China, Vol. 5. Erpodiaceae-Climaciaceae. Science Press, Beijing and Missouri Botanical Garden Press, St. Louis, MO, 423 pp.

\section{왕피천 생태경관보전지역의 육상(비관속 선태식물 및 관속식물) 식물상

\author{
이승혁 $\cdot$ 안진갑 ${ }^{1} \cdot$ 박승진 $^{1} \cdot$ 김철환 $^{2} \cdot$ 최승세 $^{3^{*}}$
} \\ 한국수목원관리원 국립백두대간수목원, ${ }^{1}$ 전북대학교 생물학과, ${ }^{2}$ 성호그린테크, ${ }^{3}$ 국립생태원 자연환경조사팀}

적 요: 본 연구는 경상북도 울진군과 영양군에 위치한 왕피천유역 생태·경관보호지역의 비관속 선태식물상 및 관속식물상을 조사하여 보전 및 지속가능한 관리방안을 수립하는데 기여하고자 하였다. 2016년 11월부터 2017년 10 월까지 계절별 현지조사를 수행하였다. 조사 결과 왕피천유역의 육상식물은 총 164 과 455속 698종 10 아종 47 변종 3 품종으로 총 758 분류군을 확인하였다. 이 중 비관속 선태식물은 46 과 88 속 120 종 2 변종으로 총 122 분류군이며, 관속식물은 118 과 367 속 578 종 10 아종 45 변종 3 품종으로 총 636 분류군이였고, 자생식물 은 693 분류군으로 집계되었다. 식물구계학적 특정식물은 총 113 분류군으로 $\mathrm{V}$ 등급 1 분류군, IV등급 6 분류군, III등급 31 분류군, II등급 38 분류군, I등급 37 분류군을 확인하였다. 한반도 고유종은 덕우기름나물을 비롯한 9 분류군이며, 희귀식물은 2 분류군, 기후변화에 취약한 북방계 15 분류군과 남방계 1 분류군이 확인되었다. 귀화 식물은 46 분류군, 생태계교란식물은 5 분류군이 조사되었다. 본 연구의 결과는 보전이 필요한 종들을 제시하 며, 왕피천 생태경관보전지역의 보전 및 관리를 위한 기초자료로 사용될 것이다.

주요어: 왕피천, 육상식물, 선태식물, 자생식물, 관리 
Appendix 1. The list of land plants investigated in Wangpicheon.

\begin{tabular}{|c|c|c|}
\hline Scientific names & \multirow[t]{2}{*}{ Korean names/Voucher numbers } & \multirow[t]{2}{*}{ Classification } \\
\hline Nonvas & & \\
\hline \multicolumn{3}{|l|}{ BRYOPHYTA 선류식물문 } \\
\hline \multicolumn{3}{|l|}{ POLYTRICHACEAE Schwägr. 솔이끼과 } \\
\hline Atrichum flavisetum Mitt. & 넓은주름솔이끼 PARK 17031163 & $\mathrm{Bt}$ \\
\hline Atrichum rhystophyllum (Müll. Hal.) Paris & 아기주름솔이끼 PARK 17031206 & $\mathrm{Te}$ \\
\hline Pogonatum inflexum (Lindb.) Lac. & 아기들솔이끼 PARK 17031166 & Ts \\
\hline Pogonatum spinulosum Mitt. & 침들솔이끼 PARK 17102425 & Ts \\
\hline Pogonatum urnigerum (Hedw.) P. Beauv. & 산들솔이끼 PARK 17031253 & $\mathrm{Mz}$ \\
\hline Polytrichastrum alpinum (Hedw.) G. L. Sm & 산솔이끼 PARK 17031177 & $\mathrm{Mz}$ \\
\hline \multicolumn{3}{|l|}{ DIPHYSCIACEAE M. Fleisch. 보리알이끼과 } \\
\hline Diphyscium fulvifolium Mitt. & 보리알이끼 PARK 17102414 & Ts \\
\hline \multicolumn{3}{|l|}{ FUNARIACEAE Schwägr. 표주박이끼과 } \\
\hline Funaria hygrometrica Hedw. & 표주박이끼 PARK 17031221 & $\mathrm{Mz}$ \\
\hline Physcomitrium eurystomum Sendtn. & 큰잎풍경이끼 PARK 17051712 & Ts \\
\hline Physcomitrium sphaericum (C. F. Ludw.) Fürnr. & 아기풍경이끼 PARK 17031263 & $\mathrm{Te}$ \\
\hline \multicolumn{3}{|l|}{ GRIMMIACEAE Arn. 고깔바위이끼과 } \\
\hline Coscinodon humilis Milde & 바위이끼 PARK 17031214 & $\mathrm{Bt}$ \\
\hline Grimmia pilifera P. Beauv. & 흰털고깔바위이끼 PARK 17031204 & $\mathrm{Bt}$ \\
\hline Racomitrium canescens (Hedw.) Brid. & 서리이끼 PARK 17051700 & $\mathrm{Bt}$ \\
\hline Racomitrium ericoides (Hedw.) Brid. & 누운서리이끼 PARK 17031254 & $\mathrm{Bt}$ \\
\hline Schistidium apocarpum (Hedw.) Bruch \& Schimp. & 고깔바위이끼 PARK 17031238 & $\mathrm{Mz}$ \\
\hline \multicolumn{3}{|l|}{ PTYCHOMITRIACEAE Schimp. 곱슬이끼과 } \\
\hline Ptychomitrium dentatum (Mitt.) A. Jaeger. & 물가곱슬이끼 PARK 17031186 & $\mathrm{Te}$ \\
\hline Ptychomitrium linearifolium Reimers \& Sakurai & 돌주름곱슬이끼 PARK 17031187 & $\mathrm{Te}$ \\
\hline \multicolumn{3}{|l|}{ FISSIDENTACEAE Schimp. 봉황이끼과 } \\
\hline Fissidens dubius P.Beauv. & 벼슬봉황이끼 PARK 17031175 & $\mathrm{Bt}$ \\
\hline Fissidens gymnogynus Besch. & 작은봉황이끼 PARK 17102454 & $\mathrm{Te}$ \\
\hline \multicolumn{3}{|l|}{ DITRICHACEAE Limpr. 금실이끼과 } \\
\hline Ceratodon purpureus (Hedw.) Brid. & 지붕빨간이끼 PARK 17051716 & $\mathrm{Mz}$ \\
\hline \multicolumn{3}{|l|}{ RHABODOWEISIACEAE Limpr. 주름꼬마이끼과 } \\
\hline Oncophorus crispifolius (Mitt.) Lindb. & 곱슬혹이끼 PARK 17051737 & Ts \\
\hline \multicolumn{3}{|l|}{ DICRANACEAE Schimp. 꼬리이끼과 } \\
\hline Dicranella heteromalla (Hedw.) Schimp. & 억새이끼 PARK 17102418 & $\mathrm{Bt}$ \\
\hline Dicranum nipponense Besch. & 큰꼬리이끼 PARK 17031261 & $\mathrm{Bt}$ \\
\hline \multicolumn{3}{|l|}{ LEUCOBRYACEAE Schimp. 흰털이끼과 } \\
\hline Brothera leana (Sull.) Müll. Hal. & 사자이끼 $P A R K 17051719$ & $\mathrm{Bt}$ \\
\hline Campylopus sinensis (Müll. Hal.) J. P. Frahm & 붓이끼 PARK 17031165 & $\mathrm{Te}$ \\
\hline Campylopus umbellatus (Schwägr. \& Gaudich. ex Arn.) Paris & 아기붓이끼 PARK17031213 & St \\
\hline Leucobryum juniperoideum (Brid.) Müll. Hal. & 가는흰털이끼 PARK 17031171 & $\mathrm{Te}$ \\
\hline POTTIACEAE Schimp. 침 꼬마이끼과 & & \\
\hline
\end{tabular}


Appendix 1. Continued.

Didymodon rigidulus Hedw.

Oxystegus tenuirostris (Hook. \& Taylor) A. J. E. Sm.

Weisiopsis anomala (Broth. \& Paris) Broth. \& Paris

Weissia controversa Hedw.

BRYACEAE Schwägr. 참이끼과

Anomobryum filiforme var. concinnatum (Spruce) Loeske

Brachymenium nepalense Hook.

Bryum argenteum Hedw.

Bryum pseudotriquetrum (Hedw.) P. Gaertn.

MNIACEAE Schwägr. 초롱이끼과

Plagiomnium maximoviczii (Lindb.) T. J. Kop.

Pohlia flexuosa Harv.

Pohlia proligera (Kindb.) Broth.

BARTRAMIACEAE Schwägr. 구슬이끼과

Bartramia pomiformis Hedw.

Philonotis falcata (Hook.) Mitt.

Philonotis turneriana (Schwägr.) Mitt.

ORTHOTRICHACEAE Arn. 선주름이끼과

Macromitrium japonicum Dozy \& Molk.

HEDWIGIACEAe Schimp. 톳이끼과

Hedwigia ciliata (Hedw.) P. Beauv.

AMBLYSTEGIACEAE G. Roth 버들이끼과

Campylium chrysophyllum (Brid.) Lange

Campylium stellatum (Hedw.) C. E. O. Jensen

Leptodictyum riparium (Hedw.) Warnst.

LESKEACEAE Schimp. 고깔검정이끼과

Claopodium pellucinerve (Mitt.) Best

Haplocladium angustifolium (Hampe \& Müll. Hal.) Broth.

Haplocladium strictulum (Cardot) Reim.

Pseudoleskeopsis zippelii (Dozy \& Molk.) Broth.

THUIDIACEAE Schimp. 깃털이끼과

Fauriella tenuis (Mitt.) Cardot

Thuidium cymbifolium (Dozy \& Molk.) Dozy \& Molk.

Thuidium kanedae Sakurai

BRACHYTHECIACEAE Schimp. 양털이끼과

Brachythecium buchananii (Hook.) A. Jaeger.

Brachythecium helminthocladum Broth. \& Paris

Brachythecium plumosum (Hedw.) Schimp.

Brachythecium populeum (Hedw.) Schimp.

Brachythecium rivulare Schimp.

\begin{tabular}{|c|c|}
\hline 곧은쌍둥이이끼 PARK 17031217 & $\overline{\mathrm{Mz}}$ \\
\hline 통수염이끼 PARK 17031209 & $\mathrm{Mz}$ \\
\hline 겉꼬마이끼 PARK 17102447 & $\mathrm{Te}$ \\
\hline 꼬마이끼 PARK 17031188 & $\mathrm{Mz}$ \\
\hline 처녀겉은이끼 PARK 17102405 & $\mathrm{Mz}$ \\
\hline 노란참외이끼 PARK 17051715 & Ts \\
\hline 은이끼 PARK 17031264 & $\mathrm{Mz}$ \\
\hline 큰철사이끼 $P A R K 17102434$ & $\mathrm{Mz}$ \\
\hline 덩굴초롱이끼 PARK 17031247 & $\mathrm{Su}$ \\
\hline 털수세미이끼 PARK 17031193 & St \\
\hline 흙들수세미이끼 PARK 17031168 & $\mathrm{Bt}$ \\
\hline 구슬이끼 PARK 17031184 & $\mathrm{Bt}$ \\
\hline 낫물가이끼 PARK 17031231 & Ts \\
\hline 큰물가이끼 PARK 17031198 & St \\
\hline 긴금털이끼 PARK 17051703 & $\mathrm{Bt}$ \\
\hline 톳이끼 PARK 17031239 & $\mathrm{Mz}$ \\
\hline 가는노란변덕이끼 PARK 17031208 & $\mathrm{Bt}$ \\
\hline 변덕이끼 PARK 17102407 & $\mathrm{Bt}$ \\
\hline 가는그물이끼 PARK 17031212 & $\mathrm{Mz}$ \\
\hline 아기가시이끼 PARK 17031246 & $\mathrm{Bt}$ \\
\hline 침작은명주실이끼 $P A R K 17102474$ & $\mathrm{Te}$ \\
\hline 물가작은명주실이끼 PARK 17031237 & $\mathrm{Bt}$ \\
\hline 물바위이끼 PARK 17031230 & St \\
\hline 수염이끼 PARK 17031251 & Ts \\
\hline 물가깃털이끼 PARK 17031257 & $\mathrm{Mz}$ \\
\hline 깃털이끼 PARK 17031196 & Ts \\
\hline 긴양털이끼 PARK 17031216 & $\mathrm{Te}$ \\
\hline 끈양털이끼 PARK 17031200 & $\mathrm{Te}$ \\
\hline 날개양털이끼 PARK 17031162 & $\mathrm{Mz}$ \\
\hline 양털이끼 PARK 17102427 & $\mathrm{Te}$ \\
\hline 물가양털이끼 PARK 17031176 & $\mathrm{Bt}$ \\
\hline
\end{tabular}


Appendix 1. Continued.

Bryhnia hultenii E.B. Bartram

Bryhnia novae-angliae (Sull. \& Lesq.) Grout

Eurhynchium hians (Hedw.) Sande Lac.

Myuroclada maximowiczii (G. G. Borshch.) Steere \& W. B. Schofield

Okamuraea brachydictyon (Cardot) Nog.

HYPNACEAE Schimp. 털깃털이끼과

Callicladium haldanianum (Grev.) H. A. Crum

Eurohypnum leptothallum (Müll. Hal.) Ando

Gollania ruginosa (Mitt.) Broth.

Herzogiella turfacea (Lindb.) Z. Iwats.

Homomallium japonico-adnatum (Broth.) Broth.

Hypnum oldhamii (Mitt.) A. Jaeger

Taxiphyllum aomoriense (Besch.) Z. Iwats.

Taxiphyllum taxirameum (Mitt.) M. Fleisch.

HYLOCOMIACEAE M. Fleisch. 수풀이끼과

Ctenidium capillifolium (Mitt.) Broth.

Rhytidiadelphus japonicus (Reimers) T. J. Kop.

PLAGIOTHECIACEAE (Broth.) M. Fleisch. 산주목이끼과

Plagiothecium nemorale (Mitt.) A. Jaeger.

ENTODONTACEAE Kindb. 윤이끼과

Entodon challengeri (Paris) Cardot

Entodon flavescens (Hook.) A. Jaeger.

Entodon sullivantii (Müll. Hal.) Lindb.

PYLAISIADELPHACEAE Goffinet \& W. R. Buck 털거울이끼과

Pylaisiadelpha yokohamae (Broth.) W. R. Buck

SEMATOPHYLLACEAE Broth. 무성아실이끼과

Sematophyllum subhumile (Müll. Hal.) M. Fleisch.

NECKERACEAE Schimp. 납작이끼과

Thamnobryum plicatulum (Sande Lac.) Z. Iwats.

ANOMODONTACEAE Kindb. 명주실이끼과

Anomodon giraldii Müll. Hal.

Anomodon minor (Hedw.) Lindb.

Herpetineuron toccoae (Sull. \& Lesq.) Cardot

Schwetschkeopsis fabronia (Schwägr.) Broth.

Schwetschkeopsis robustula (Broth.) Ando

MARCHANTIOPHYTA 태류식물문

MARCHANTIACEAE 우산이끼과

Marchantia paleacea Bertol.

Marchantia polymorpha L.

AYTONIACEAE 삿갓우산이끼과
뽀족화살이끼 PARK 17051711

Bt

곱슬세모양털이끼 PARK 17031183

물가침부리이끼 PARK 17051710

쥐꼬리이끼 PARK 17031207

가는겉양털이끼 PARK 17031190

풀이끼 PARK 17031170

산누운깃털이끼 PARK 17031241

주름사슴뿔이끼 PARK 17031256-1

누운아기주목이끼 PARK 17051730

들쌍긑양털이끼 PARK 17031234

가는털깃털이끼 PARK 17031178

겹친주목이끼 PARK 17031211

주목이끼 PARK 17031180

아기머리빗이끼 PARK 17031210

Ts

아기겉굵은이끼 PARK 17102472

Bt

산주목이끼 PARK 17051727

$\mathrm{Mz}$

넓은잎윤이끼 PARK 17051714

Bt

가지윤이끼 PARK 17102460

$\mathrm{Bt}$

가는윤이끼 PARK 17031191

Bt

털거울이끼 PARK 17031255

Ts

무성아실이끼 PARK 17031174

$\mathrm{St}$

그늘대호꼬리이끼 PARK 17031243

Ts

큰명주실이끼 PARK 17031224

Bt

푸른명주실이끼 PARK 17031189

Bt

나선이끼PARK 17031192

$\mathrm{St}$

개털이끼 $P A R K 17102461$

$\mathrm{Te}$

큰개털이끼 PARK 17102458

$\mathrm{Te}$

윤기우산이끼 $\mathrm{CHOI} 170041$

$\mathrm{Mz}$

우산이끼 $\mathrm{CHOI} 170064$

$\mathrm{Mz}$ 
Appendix 1. Continued.

\begin{tabular}{|c|c|c|}
\hline Plagiochasma japonicum (Steph.) C. Massal. & 버섯우산이끼 CHOI $170058 a$ & $\mathrm{Te}$ \\
\hline \multicolumn{3}{|l|}{ CONOCEPHALACEAE 패랭이우산이끼과 } \\
\hline Conocephalum conicum (L.) Underw. & 패랭이우산이끼 CHOI 170038 & Bo \\
\hline Conocephalum japonicum (Thunb.) Grolle & 아기패랭이우산이끼 $\mathrm{CHOI} 170050 \mathrm{c}$ & $\mathrm{Mz}$ \\
\hline \multicolumn{3}{|l|}{ RICCIACEAE 둥근이끼과 } \\
\hline Riccia fluitans $\mathrm{L}$. & 물긴가지이끼 PARK 17102433 & $\mathrm{Mz}$ \\
\hline \multicolumn{3}{|l|}{ PELLIACEAE 물우산대이끼과 } \\
\hline Pellia endiviifolia (Dicks.) Dumort. & 가는물우산대이끼 CHOI 170033 & Bo \\
\hline \multicolumn{3}{|l|}{ ANEURACEAE 초록우산대이끼과 } \\
\hline Aneura maxima (Schiffner) Steph. & 큰초록우산대이끼 CHOI 170036 & $\mathrm{Mz}$ \\
\hline Aneura pinguis (L.) Dumort. & 초록우산대이끼 CHOI 170070 & $\mathrm{Mz}$ \\
\hline \multicolumn{3}{|l|}{ PORELLACEAE 세줄이끼과 } \\
\hline Porella caespitans var. cordifolia $\mathrm{S}$. Hatt. & 침세줄이끼 CHOI 170055 & Ts \\
\hline Porella stephaniana (C. Massal.) S. Hatt. & 동강세줄이끼 CHOI 170061 & $\mathrm{Te}$ \\
\hline Porella chinensis (Steph.) S. Hatt. & 덕항세줄이끼 PARK 17102444 & $\mathrm{Te}$ \\
\hline \multicolumn{3}{|l|}{ RADULACEAE 부채이끼과 } \\
\hline Radula japonica Gottsche & 부채이끼 $C H O I 170067 b$ & Ts \\
\hline Radula constricta Steph. & 무성아부채이끼 PARK 17051734 & $\mathrm{Bt}$ \\
\hline \multicolumn{3}{|l|}{ FRULLANIACEAE 지네이끼과 } \\
\hline Frullania taradakensis Steph. & 들지네이끼 CHOI 170053 & $\mathrm{Su}$ \\
\hline Frullania muscicola Steph. & 참지네이끼 CHOI 170063 & $\mathrm{Te}$ \\
\hline Frullania appendiculata Steph. & 침지네이끼 PARK 17051702 & Ts \\
\hline \multicolumn{3}{|l|}{ LEJEUNEACEAE 작은귀이끼과 } \\
\hline Lejeuena japonica Mitt. & 작은귀이끼 CHOI 170040 & Ts \\
\hline Lejeuena compacta (Steph.) Steph. & 잎작은귀이끼 CHOI 170048 & $\mathrm{Su}$ \\
\hline Cololejeunea macounii (Spruce ex Underw.) A. Evans & 혹귀이끼 PARK 17102415 & Ts \\
\hline \multicolumn{3}{|l|}{ PSEUDOLEPICOLACEAE 솔잎이끼과 } \\
\hline Blepharostoma minus Horik. & 솔잎이끼 CHOI 170042 & $\mathrm{Te}$ \\
\hline \multicolumn{3}{|l|}{ LOPHOCOLEACEAE 두끝벼슬이끼과 } \\
\hline Lophocolea minor Nees & 아기두끝벼슬이끼 CHOI 170054 & $\mathrm{Ab}$ \\
\hline Heteroscyphus planus (Mitt.) Schiffn. & 비늘이끼 CHOI 170051 & $\mathrm{Su}$ \\
\hline Chiloscyphus polyanthos (L.) Corda & 물비늘이끼 CHOI 170057 & Bo \\
\hline \multicolumn{3}{|l|}{ PLAGIOCHILACEAE 날개이끼과 } \\
\hline Pedinophyllum truncatum (Steph.) Inoue & 누운날개이끼 CHOI 170060 & $\mathrm{Te}$ \\
\hline Plagiochila porelloides (Torrey in Nees) Lindenb. & 숲날개이끼 CHOI 170069 & $\mathrm{Ab}$ \\
\hline \multicolumn{3}{|l|}{ JAMESONIELLACEAE 가을비늘이끼과 } \\
\hline Crossogyna autumnalis (DC.) Schljakov & 가을비늘이끼 CHOI 170035 & $\mathrm{Te}$ \\
\hline \multicolumn{3}{|l|}{ CALYPOGEIACEAE 들목걸이이끼과 } \\
\hline Calypogeia tosana (Steph.) Steph. & 들목걸이이끼 $C H O I 170034 a$ & $\mathrm{Te}$ \\
\hline \multicolumn{3}{|l|}{ DELAVAYELLACEAE 꼭지망울이끼과 } \\
\hline Liochlaena subulata (A. Evans) Schljakov & 꼭지망울이끼 CHOI 170045 & $\mathrm{Bt}$ \\
\hline
\end{tabular}


Appendix 1. Continued.

SOLENOSTOMATACEAE 둥근망울이끼과

Nardia assamica (Mitt.) Amak.

빨간비늘이끼 PARK 17102439

$\mathrm{Ab}$

Plectocolea infusca Mitt.

Plectocolea ovalifolia (Amakawa) Bakalin \& Vilnet

큰망울이끼 CHOI $170068 a$

Ts

누운큰망울이끼 CHOI $170050 a$

$\mathrm{Bt}$

Solenostoma minutissimum (Amakawa) Bakalin

탐라망울이끼 PARK 17102448

Ts

Solenostoma rotundatum Amak

산망울이끼 PARK 17102461

Ts

ANTHOCEROPHYTA 뿔이끼식물문

ANTHOCEROTACEAE 뿔이끼과

Anthoceros punctatus L.

뿔이끼 PARK 17102420

$\mathrm{Te}$

NOTOTHYLACEAE 짧은뿔이끼과

Phaeoceros carolinianus (Michx.) Prosk.

마당뿔이끼 PARK 17102429

$\mathrm{Mz}$

Vascular plants

PTERIDOPHYTA 양치식물문

LYCOPODIOPSIDA 석송강

SELAGINELLACEAE Willk. 부처손과

Selaginella rossii (Baker) Warb.

Selaginella tamariscina (P. Beauv.) Spring

PSILOTOPSIDA 솔잎난강

OPHIOGLOSSACEAE (R. Br.) C. Agardh 고사리삼과

Botrychium japonicum (Prantl) Underw.

산꽃고사리삼 $A H N \& L E E 4055$

III

EQUISETOPSIDA 속새강

EQUISETACEAE DC. 속새과

Equisetum arvense L.

Equisetum hyemale L.

POLYPODIOPSIDA 고사리강

OSMUNDACEAE Martinov 고비과

Osmunda cinnamomea $\mathrm{L}$.

Osmunda japonica Thunb.

HYMENOPHYLLACEAE Mart. 처녀이끼과

Crepidomanes minutum (Blume) K. Iwats.

DENNSTAEDTIACEAE Lotsy 잔고사리과

Dennstaedtia hirsuta (Sw.) Miq.

Dennstaedtia wilfordii (T. Moore) H. Christ

Pteridium aquilinum var. latiusculum (Desv.) A. Heller

PTERIDACEAE Rchb. 봉의꼬리과

Cheilanthes argentea (S. G. Gmel.) Kunze

뀡고비 $A H N$ \& $L E E 4140$

II

고비 $A H N \& L E E 4159,4751$

부채괴불이끼 $A H N \& L E E 4694$

II

잔고사리 $A H N \& L E E 4482$

황고사리 $A H N \& L E E 4304,4601$

고사리 $A H N \& L E E 4799$

부싯깃고사리 $A H N \& L E E 4056$

I

ASPLENIACEAE Newman 꼬리고사리과

Asplenium castaneo-viride Baker

Asplenium incisum Thunb.

Asplenium ruprechtii Sa. Kurata

거미꼬리고사리 $A H N \& L E E 4690$

II

꼬리고사리 $A H N \& L E E 4750$

거미고사리 $A H N \& L E E 4029$

THELYPTERIDACEAE Pic. Serm. 처녀고사리과 
Appendix 1. Continued.

Thelypteris palustris (A. Gray) Schott

WOODSIACEAE (Hook.) Herter 우드풀과

Woodsia macrochlaena Kuhn

Woodsia manchuriensis Hook.

Woodsia polystichoides D. C. Eaton

Woodsia subcordata Turcz.

ATHYRIACEAE Alston 개고사리과

Athyrium niponicum (Mett.) Hance

Athyrium sinense Rupr.

Athyrium yokoscense (Franch. \& Sav.) H. Christ

Deparia conilii (Franch. \& Sav.) M. Kato

Deparia japonica (Thunb.) M. Kato

Deparia pseudoconilii (Seriz.) Seriz.

Deparia orientalis (Z. R. Wang et J.J. Chien) Nakaike

Deparia pycnosora (H. Christ) M. Kato

ONOCLEACEAE Pic. Serm. 야산고비과

Matteuccia struthiopteris (L.) Tod.

Onoclea sensibilis L.

Pentarhizidium orientalis (Hook.) Hayata

DRYOPTERIDACEAE Herter 관중과

Dryopteris bissetiana (Baker) C. Chr.

Dryopteris chinensis (Baker) Koidz.

Dryopteris crassirhizoma Nakai

Dryopteris lacera (Thunb.) Kuntze

Dryopteris monticola (Makino) C. Chr.

Dryopteris sacrosancta Koidz.

Dryopteris saxifraga $\mathrm{H}$. Itô

Polystichum craspedosorum (Maxim.) Diels

Polystichum tripteron (Kunze) C. Presl

DAVALLIACEAE A. B. Frank 넉줄고사리과

Davallia mariesii Baker

POLYPODIACEAE Bercht. \& J. Presl 고란초과

Lepisorus ussuriensis (Regel \& Maack) Ching

Pyrrosia linearifolia (Hook.) Ching

Pyrrosia petiolosa (H. Christ) Ching

PINOPHYTA 나자식물문

GINKGOOPSIDA 은행나무강

GINKGOACEAE Engl. 은행나무과

Ginkgo biloba $\mathrm{L}$.
처녀고사리 $A H N \& L E E 4508,4676$

참우드풀 $A H N \& L E E 4384,4559$

IV

만주우드풀 $A H N \& L E E 4569$

우드풀 $A H N \& L E E 4203,4483$

산우드풀 $A H N \& L E E 4425$

II

개고사리 $A H N \& L E E 4298,4565$

참새발고사리 $A H N \& L E E 4127,4583$

뱀고사리 $A H N \& L E E 4308$

좀진고사리 $A H N \& L E E 4342,4509$

진고사리 $A H N \& L E E 4505$

나도좀진고사리 $A H N \& L E E 4520$

흰털고사리 $A H N \& L E E 4301$

털고사리 $A H N \& L E E 4589$

청나래고사리 $A H N \& L E E 4131$

야산고비 $A H N \& L E E 4516$

개면마 $A H N \&$ \&EE 4063

산족제비고사리 $A H N \& L E E 4297$

가는잎족제비고사리 $A H N \& L E E 4765$

관중 $A H N \& L E E 4112,4588$

비늘고사리 $A H N \& L E E 4135,4442$

왕지네고사리 $A H N \& L E E$ 4132, 4475

애기족제비고사리 $A H N \& L E E 4766$

바위족제비고사리 $A H N \& L E E 4032$

낚시고사리 $A H N \& L E E 4014$

십자고사리 $A H N \& L E E 4485,4711$

넉줄고사리 $A H N \& L E E 4437,4687$

산일엽초 $A H N \& L E E 4025,4714$

우단일엽 $A H N \&$ LEE 4012

애기석위 $A H N \& L E E 4767$

II

은행나무 $A H N \&$ LEE 4768

PINOPSIDA 소나무강

PINACEAE F. Rudolphi 소나무과 
Appendix 1. Continued.

Abies holophylla Maxim.

Larix kaempferi (Lamb.) Carriére

Pinus densiflora Siebold \& Zucc.

Pinus koraiensis Siebold \& Zucc.

Pinus rigida Mill.

CUPRESSACEAE Gray 측백나무과

Chamaecyparis pisifera (Siebold \& Zucc.) Endl.

MAGNOLIOPHYTA 현화식물문

MAGNOLIOPSIDA 목련강

MAGNOLIIDAE 목련아강

MAGNOLIACEAE Juss. 목련과

Liriodendron tulipifera $\mathrm{L}$.

Magnolia sieboldii K. Koch

CHLORANTHACEAE Sims 홀아비꽃대과

Chloranthus japonicus Siebold

ARISTOLOCHIACEAE Juss. 쥐방울덩굴과

Asarum sieboldii $\mathrm{Miq}$.

SCHISANDRACEAE Blume 오미자과

Schisandra chinensis (Turcz.) Baill.

CERATOPHYLLACEAE Gray 붕어마름과

Ceratophyllum demersum $\mathrm{L}$.

RANUNCULACEAE Juss. 미나리아재비과

Aconitum jaluense Kom.

Anemone raddeana Regel

Cimicifuga dahurica (Fisch. \& C. A. Mey) Maxim.

Cimicifuga heracleifolia var. bifida Nakai

Clematis apiifolia DC.

Clematis heracleifolia DC.

Clematis patens C. Morren \& Decne.

Clematis trichotoma Nakai

Eranthis stellata Maxim.

Hepatica asiatica Nakai

Pulsatilla cernua var. koreana (Nakai) U. C. L.

Ranunculus cantoniensis DC.

Ranunculus japonicus Thunb.

Ranunculus sceleratus L.

Thalictrum aquilegifolium var. sibiricum Regel \& Tiling

MENISPERMACEAE Juss. 새모래덩굴과

Cocculus trilobus (Thunb.) DC.

Menispermum dauricum DC.
전나무 $A H N \& L E E 4593$

II, Nor

일본잎갈나무 $A H N \& L E E 4769$

소나무 $A H N \& L E E 4234,4761$

잣나무 $A H N \& \operatorname{LEE} 4770$

리기다소나무 $A H N \& L E E 4771$

화백 $A H N \& L E E 4053$

c

II, c

c

C

튤립나무 $A H N \& L E E 4772$

c

함박꽃나무 $A H N \& L E E 4128$

II

홀아비꽃대 $A H N \& L E E 4136$

I

족도리풀 $A H N \& L E E 4104$

오미자 $A H N \& L E E 4587$

II

붕어마름 $A H N \& L E E 4724$

투구꽃 $A H N \& L E E 4773$

I

꿩의바람꽃 $A H N \& L E E 4037$

눈빛승마 $A H N \& L E E 4486,4585$

세잎승마 $A H N \& L E E 4341,4567$

IV, e

사위질빵 $A H N \& L E E 4287$

병조희풀 $A H N \& L E E 4392$

큰꽃으아리 $A H N \& L E E 4223$

할미밀망 $A H N \&$ LEE 4097, 4358

너도바람꽃 $A H N \& L E E 4013$

노루귀 $A H N \&$ LEE 4039

할미꽃 $A H N \& L E E 4175$

털개구리미나리 $A H N \& L E E 4412$

미나리아재비 $A H N \& L E E 4227$

개구리자리 $A H N \& L E E 4088$

뀡의다리 $A H N \& L E E 4378$

댕댕이덩굴 $A H N \& L E E 4280,4433$

새모래덩굴 $A H N \& L E E 4188$

PAPAVERACEAE Juss. 양귀비과 
Appendix 1. Continued.

Chelidonium majus var. asiaticum (H. Hara) Ohwi

FUMARIACEAE Marquis 현호색과

Corydalis pauciovulata Ohwi

Corydalis remota Maxim.

Corydalis speciosa Maxim.

Dicentra spectabilis (L.) Lem.

HAMAMELIDAE 조록나무아강

EUCOMMIACEAE Engl. 두충과

Eucommia ulmoides Oliv.

ULMACEAE Mirb. 느릅나무과

Celtis koraiensis Nakai

Celtis sinensis Pers.

Ulmus davidiana var. japonica (Rehder) Nakai

CANNABACEAE Martinov 삼과

Humulus japonicus Siebold \& Zucc.

MORACEAE Gaudich. 뽕나무과

Broussonetia kazinoki Siebold \& Zucc.

Morus alba L.

Morus bombycis Koidz.

URTICAEAE Juss. 쐐기풀과

Boehmeria longispica Steud.

Boehmeria spicata (Thunb.) Thunb.

Pilea japonica (Maxim.) Hand.-Mazz.

Pilea mongolica Wedd.

JUGLANDACEAE Perleb 가래나무과

Juglans mandshurica Maxim.

FAGACEAE Dumort. 참나무과

Castanea crenata Siebold \& Zucc.

Quercus aliena Blume

Quercus dentata Thunb.

Quercus mongolica Ledeb.

Quercus serrata Murray

Quercus variabilis Blume

BETULACEAE Gray 자작나무과

Alnus firma Siebold \& Zucc.

Alnus hirsuta Rupr.

Alnus japonica (Thunb.) Steud.

Betula dahurica Pall.

Betula pendula Roth

Betula schmidtii Regel

Carpinus cordata Blume
애기똥풀 $A H N \& L E E 4218$

선괴불주머니 $A H N \& L E E 4603$

현호색 $A H N \& L E E$ 4026, 4038

산괴불주머니 $A H N \& L E E$ 4031, 4106

금낭화 $A H N \& L E E 4102$

II

두충 $A H N \& L E E 4774$

c

왕팽나무 $A H N \& L E E 4775$

III

팽나무 $A H N \& L E E 4776$

느릅나무 $A H N \& L E E 4095$

환삼덩굴 $A H N \& L E E 4777$

d

닥나무 $A H N \& L E E 4073$

뽕나무 $A H N \& L E E 4119$

산뽕나무 $A H N \& L E E 4123,4194$

왜모시풀 $A H N \& L E E 4334$

좀깨잎나무 $A H N \& L E E 4263$

산물통이 $A H N \&$ LEE 4709

모시물통이 $A H N \& L E E 4618$

가래나무 $A H N \& L E E 4111$

밤나무 $A H N \& L E E 4338$

갈참나무 $A H N \& L E E 4510$

떡갈나무 $A H N \& L E E 4467$

신갈나무 $A H N \& L E E$ 4396, 4759

졸참나무 $A H N \& L E E 4695$

굴참나무 $A H N \& L E E 4452,4722$

사방오리 $A H N \& L E E 4778$

c

물오리나무 $A H N \& L E E 4002,4717$

오리나무 $A H N \& L E E 4448,4729$

물박달나무 $A H N \& L E E$ 4403, 4507 III

자작나무 $A H N \& L E E 4339 \quad$ c

박달나무 $A H N \& L E E 4688$ III

까치박달 $A H N \& L E E 4098$ 
Appendix 1. Continued.

Corylus heterophylla Trautv.

Corylus sieboldiana Blume

CARYOPHYLLIDAE 석죽아강

PHYTOLACCACEAE R. Br. 자리공과

Phytolacca americana L.

CHENOPODIACEAE Vent. 명아주과

Chenopodium album $\mathrm{L}$.

Chenopodium ambrosioides $\mathrm{L}$.

Chenopodium ficifolium $\mathrm{Sm}$.

AMARANTHACEAE Juss. 비름과

Achyranthes japonica (Miq.) Nakai

Amaranthus lividus L.

Amaranthus retroflexus $\mathrm{L}$.

PORTULACACEAE Juss. 쇠비름과

Portulaca oleracea L.

CARYOPHYLLACEAE Juss. 석죽과

Cucubalus baccifer var. japonicus Miq.

Dianthus chinensis L.

Gypsophila oldhamiana Miq.

Lychnis cognata Maxim.

Pseudostellaria heterophylla (Miq.) Pax

Pseudostellaria palibiniana (Takeda) Ohwi

Sagina japonica (Sw.) Ohwi

Silene armeria $\mathrm{L}$.

Silene firma Siebold \& Zucc.

Silene seoulensis Nakai

Stellaria alsine var. undulata (Thunb.) Ohwi

Stellaria aquatica (L.) Scop.

Stellaria media (L.) Vill.

POLYGONACEAE Juss. 마디풀과

Fallopia dumetorum (L.) Holub

Fallopia forbesii (Hance) Yonek. \& H. Ohashi

Polygonum aviculare L.

Polygonum dissitiflorum Hemsl.

Polygonum japonicum Meisn.

Polygonum lapathifolium L.

Polygonum longisetum Bruijn

Polygonum maackianum Regel

Polygonum nepalense Meisn.

Polygonum perfoliatum L.

Polygonum persicaria L.
난티잎개암나무 $A H N \& L E E 4779$

참개암나무 $A H N \& L E E 4502$

미국자리공 $A H N \& L E E 4421$

$\mathrm{n}$

흰명아주 $A H N \& L E E 4429 \quad \mathrm{n}$

양명아주 $A H N \& L E E 4780 \quad \mathrm{n}$

좀명아주 $A H N \& L E E 4781$

쇠무릎 $A H N \& L E E 4614$

개비름 $A H N \& L E E 4290$

n

털비름 $A H N \& L E E 4606$

쇠비름 $A H N \& L E E 4283$

덩굴별꽃 $A H N \& L E E 4359$

패랭이꽃 $A H N \& L E E 4242,4635$

대나물 $A H N \& L E E 4320$

동자꽃 $A H N \& L E E 4416$

II

개별꽃 $A H N \& L E E 4142$

큰개별꽃 $A H N \& L E E 4030$

개미자리 $A H N \& L E E 4517,4669$

끈끈이대나물 $A H N \& L E E 4782$

$\mathrm{c}, \mathrm{n}$

장구채 $A H N \& L E E 4337$

가는장구채 $A H N \& L E E 4303,4621$

벼룩나물 $A H N \& L E E 4216$

쇠별꽃 $A H N$ \& $L E E 4206$

별꽃 $A H N \& L E E 4015,4043$

닭의덩굴 $A H N \& L E E 4235$

감절대 $A H N \& L E E 4453$

마디풀 $A H N \& L E E 4355$

가시여뀌 $A H N$ \& LEE 4610

흰꽃여뀌 $A H N \& L E E 4231,4660$

흰여뀌 $A H N \&$ \&EE 4783

개여뀌 $A H N \&$ \&EE 4764

나도미꾸리낚시 $A H N \& L E E 4292$

산여뀌 $A H N \& L E E 4784$

며느리배꼽 $A H N \& L E E 4230$

봄여뀌 $A H N \& L E E 4260,4422$ 
Appendix 1. Continued.

Polygonum posumbu D. Don

Polygonum sagittatum L.

Polygonum senticosum (Meisn.) Franch. \& Sav.

Polygonum thunbergii Siebold \& Zucc.

Rumex acetosa $\mathrm{L}$.

Rumex acetosella L.

DILLENIIDAE 딜레니아아강

PAEONIACEAE Raf. 작약과

Paeonia japonica (Makino) Miyabe \& Takeda

ACTINIDIACEAE Gilg \& Werderm. 다래나무과

Actinidia arguta (Siebold \& Zucc.) Miq.

Actinidia polygama (Siebold \& Zucc.) Maxim.

CLUSIACEAE Lindl. 물레나물과

Hypericum ascyron $\mathrm{L}$.

Hypericum erectum Thunb.

Hypericum japonicum Thunb.

Hypericum laxum (Blume) Koidz.

Triadenum japonicum (Blume) Makino

TILIACEAE Juss. 피나무과

Corchoropsis tomentosa (Thunb.) Makino

Tilia mandshurica Rupr. \& Maxim.

Tilia rufa (Nakai) Nakai

Tilia taquetii C. K. Schneid.

DROSERACEAE Salisb. 끈끈이귀개과

Drosera rotundifolia $\mathrm{L}$.

VIOLACEAE Batsch 제비꽃과

Viola acuminata Ledeb.

Viola albida var. chaerophylloides (Regel) F. Maek.

Viola collina Besser

Viola lactiflora Nakai

Viola mandshurica W. Becker

Viola orientalis (Maxim.) W. Becker

Viola variegata Link.

Viola verecunda A. Gray

SALICACEAE Mirb. 버드나무과

Populus davidiana Dode

Populus nigra var. italica Koehne

Salix caprea L.

Salix chaenomeloides Kimura

Salix graciliglans Nakai

Salix gracilistyla Miq.
장대여뀌 $A H N \& L E E$ 4477, 4597

미꾸리낚시 $A H N \& L E E$ 4233, 4268

며느리밑씻개 $A H N \& L E E 4236$

고마리 $A H N \& L E E 4668,4756$

수영 $A H N \& L E E 4198$

애기수영 $A H N \& L E E 4294$

n, d

백작약 $A H N \& L E E 4785$

II, NT

다래 $A H N \& L E E 4515$

개다래 $A H N \& L E E 4286$

물레나물 $A H N \& L E E 4306$

고추나물 $A H N \& L E E 4331,4537$

애기고추나물 $A H N \& L E E 4497,4545$

좀고추나물 $A H N \& L E E 4741$

물고추나물 $A H N \& L E E 4536,4746$

III

수까치깨 $A H N \& L E E 4701$

찰피나무 $A H N \& L E E 4113,4277$

II

털피나무 $A H N \& L E E 4786$

II

뽕잎피나무 $A H N \& L E E 4787$

근근이주걱 $A H N \&$ \&EE 4064, 4542

II

졸방제비꽃 $A H N \& L E E 4185$

남산제비꽃 $A H N \& L E E 4148$

둥근털제비꽃 $A H N \& L E E$ 4054, 4105

흰젖제비꽃 $A H N \& L E E 4521$

제비꽃 $A H N \& L E E 4170,4187$

노랑제비꽃 $A H N \& L E E 4001$

II

알록제비꽃 $A H N \& L E E 4788$

콩제비꽃 $A H N \& L E E 4178$

사시나무 $A H N \& L E E 4150$

양버들 $A H N \& L E E 4789$

호랑버들 $A H N \& L E E 4007,4057$

왕버들 $A H N \&$ LEE 4790

눈갯버들 $A H N \& L E E 4004,4027$

갯버들 $A H N \& L E E 4005$ 
Appendix 1. Continued.

Salix koreensis Andersson

Salix koriyanagi Goerz

Salix siuzevii Seemen

Salix subfragilis Andersson

BRASSICACEAE Burnett 십자화과

Arabis glabra (L.) Bernh.

Barbarea orthoceras Ledeb.

Berteroella maximowiczii (Palib.) O. E. Schulz

Capsella bursa-pastoris (L.) Medik.

Cardamine fallax (O. E. Shculz) Nakai

Cardamine impatiens L.

Cardamine leucantha (Tausch) O. E. Schulz

Draba nemorosa L.

Rorippa indica (L.) Hiern

Sisymbrium luteum (Maxim.) O. E. Schulz

ERICACEAE Juss. 진달래과

Rhododendron micranthum Turcz.

Rhododendron mucronulatum Turcz.

Rhododendron schlippenbachii Maxim.

Vaccinium hirtum var. koreanum (Nakai) Kitam.

PYROLACEAE Lindl. 노루발과

Pyrola japonica Alef.

EBENACEAE Gürke 감나무과

Diospyros kaki Thunb.

Diospyros lotus L.

STYRACACEAE DC. \& Spreng. 때죽나무과

Styrax obassia Siebold \& Zucc.

SYMPLOCACEAE Desf. 노린재나무과

Symplocos sawafutagi Nagam.

PRIMULACEAE Borkh. 앵초과

Lysimachia clethroides Duby

Lysimachia davurica Ledeb.

ROSIDAE 장미아강

HYDRANGEACEAE Dumort. 수국과

Deutzia glabrata Kom.

Deutzia parviflora Bunge

Deutzia uniflora Shirai

Hydrangea serrata for. acuminata (Siebold \& Zucc.) E. H. Wilson Philadelphus tenuifolius Maxim.

CRASSULACEAE J. St.-Hil. 돌나물과
버드나무 $A H N \& L E E$ 4181, 4208

키버들 $A H N \&$ LEE 4006

참오굴잎버들 $A H N \& L E E 4144$

선버들 $A H N \& L E E 4186$

장대나물 $A H N \& L E E 4800$

나도냉이 $A H N \& L E E 4220$

장대냉이 $A H N \& L E E 4295$

냉이 $A H N \&$ LEE 4047

좁쌀냉이 $A H N \& L E E 4080,4164$

싸리냉이 $A H N \& L E E 4182$

미나리냉이 $A H N \& L E E 4222$

꽃다지 $A H N \&$ LEE 4018

개갓냉이 $A H N \& L E E 4217$

노란장대 $A H N \& L E E 4122$

I

꼬리진달래 $A H N \& L E E$ 4527, $4760 \quad \mathrm{IV}$, Nor

진달래 $A H N$ \& LEE 4009

철쭉 $A H N \& L E E 4094$

산앵도나무 $A H N \& L E E 4380$

III, e

노루발 $A H N \& L E E 4454$

감나무 $A H N \& L E E 4791$

c

고욤나무 $A H N \& L E E$ 4279, 4702

쪽동백나무 $A H N \& L E E$ 4137, 4299

노린재나무 $A H N \& L E E 4174$

큰까치수염 $A H N \& L E E 4484$

좁쌀풀 $A H N \& L E E 4415,4547$

III

물참대 $A H N \& L E E 4154$

말발도리 $A H N \& L E E 4133$

매화말발도리 $A H N \& L E E 4180$ I

산수국 $A H N \& L E E 4522$

엷은잎고광나무 $A H N \& L E E$ 4100, 4212

좀바위솔 $A H N \& L E E 4719$ 
Appendix 1. Continued.

Sedum kamtschaticum Fisch. \& C. A. Mey.

Sedum polytrichoides Hemsl.

Sedum sarmentosum Bunge

SAXIFRAGACEAE Juss. 범의귀과

Astilbe rubra Hook. f.

Chrysosplenium flagelliferum $\mathrm{F}$. Schmidt

Chrysosplenium japonicum (Maxim.) Makino

Mukdenia rossii (Oliv.) Koidz.

Saxifraga fortunei var. incisolobata (Engl. \& Irmsch.) Nakai

PARNASSIACEAE Martinov 물매화과

Parnassia palustris var. multiseta Ledeb.

ROSACEAE Juss. 장미과

Agrimonia coreana Nakai

Agrimonia pilosa Ledeb.

Aria alnifolia (Siebold \& Zucc.) Decne.

Crataegus pinnatifida Bunge

Geum aleppicum Jacq.

Malus baccata (L.) Borkh.

Potentilla chinensis Ser.

Potentilla fragarioides $\mathrm{L}$.

Potentilla freyniana Bornm.

Potentilla yokusaiana Makino

Prunus mandshurica var. glabra Nakai

Prunus padus L.

Prunus persica (L.) Batsch

Pyrus ussuriensis Maxim.

Rosa multiflora Thunb.

Rosa wichuraiana Crép.

Rubus crataegifolius Bunge

Rubus oldhamii Miq.

Rubus parvifolius L.

Rubus phoenicolasius Maxim.

Sanguisorba officinalis L.

Sanguisorba tenuifolia Link.

Sorbaria sorbifolia var. stellipila Maxim.

Spiraea blumei G. Don

Spiraea chamaedryfolia L.

Spiraea chinensis Maxim.

Spiraea fritschiana C. K. Schneid.

Spiraea prunifolia var. simpliciflora (Nakai) Nakai

Spiraea salicifolia L.
기린초 $A H N \&$ LEE 4197

바위채송화 $A H N \& L E E 4692$

돌나물 $A H N \& L E E 4792$

노루오줌 $A H N \& L E E 4204,4345$

애기괭이눈 $A H N \& L E E 4035$

산괭이눈 $A H N \& L E E 4016$

돌단풍 $A H N \& L E E 4022$

II, Nor

바위떡풀 $A H N \& L E E 4592$

물매화 $A H N \& L E E 4554,4736$

산짚신나물 $A H N \& L E E 4563$

짚신나물 $A H N \& L E E 4324$

팥배나무 $A H N \& L E E 4221$

산사나무 $A H N \& L E E 4489$

큰뱀무 $A H N \& L E E 4266,4623$

야광나무 $A H N \& L E E 4110$

딱지꽃 $A H N \& L E E 4285,4657$

양지꽃 $A H N \&$ LEE 4049

세잎양지꽃 $A H N \& L E E 4179$

민눈양지꽃 $A H N \& L E E 4034$

II

개살구나무 $A H N \& L E E 4491$

귀룽나무 AHN \& LEE 4061

복숭아나무 $A H N \& L E E 4229$

c

산돌배나무 $A H N \& L E E 4793$

찔레나무 $A H N \& L E E 4091$

돌가시나무 $A H N \& L E E 4463,4650$

산딸기 $A H N \&$ \&EE 4079

줄딸기 $A H N \& L E E 4177$

멍석딸기 $A H N$ \& LEE 4794

곰딸기 AHN \& LEE 4315

오이풀 $A H N \& L E E 4420$

가는오이풀 $A H N \& L E E 4469,4670$ I

쉬땅나무 $A H N \& L E E 4408$ III

산조팝나무 $A H N \& L E E 4199,4214$ I

인가목조팝나무 $A H N \& L E E 4108$ III

당조팝나무 $A H N \& L E E 4126$ III

참조팝나무 $A H N \& L E E 4428$ III

조팝나무 $A H N \& L E E 4167$

꼬리조팝나무 $A H N \& L E E 4409$ 
Appendix 1. Continued.

Stephanandra incisa (Thunb.) Zabel

FABACEAE Lindl. 콩과

Albizzia julibrissin Durazz.

Amorpha fruticosa $\mathrm{L}$.

Amphicarpaea bracteata ssp. edgeworthii (Benth.) H. Ohashi

Chamaecrista nomame (Siebold) H. Ohashi

Desmodium podocarpum DC.

Desmodium podocarpum ssp. oxyphyllum (DC.) H. Ohashi

Glycine soja Siebold \& Zucc.

Kummerowia striata (Thunb.) Schindl.

Lathyrus davidii Hance

Lespedeza bicolor Turcz.

Lespedeza cuneata (Dum. Cours.) G. Don

Lespedeza cyrtobotrya Miq.

Lespedeza maritima Nakai

Lespedeza maximowiczii C.K. Schneid.

Lespedeza thunbergii ssp. formosa (Vogel) H. Ohashi

Lotus corniculatus var. japonicus Regel

Pueraria lobata (Willd.) Ohwi

Robinia pseudoacacia L.

Sophora flavescens Aiton

Trifolium repens $\mathrm{L}$.

Vicia amoena Ser.

Vicia chosenensis Ohwi

Vicia nipponica Matsum.

Vicia unijuga A. Braun

Wisteria floribunda (Willd.) DC.

ELAEAGNACEAE Juss. 보리수나무과

Elaeagnus umbellata Thunb.

LYTHRACEAE J. St.-Hil. 부처꽃과

Ammannia coccinea Rottb.

Lythrum salicaria L.

ONAGRACEAE Juss. 바늘꽃과

Circaea cordata Royle

Epilobium amurense ssp. cephalostigma (Hausskn.) C.J. Chen, Hoch \& P.H. Raven

Oenothera odorata Jacq.

ALANGIACEAE DC. 박쥐나무과

Alangium platanifolium var. trilobum (Miq.) Ohwi

CORNACEAE Bercht. \& J. Presl 층층나무과

Cornus controversa Hemsl.
국수나무 $A H N \& L E E 4166,4443$

자귀나무 $A H N \& L E E 4438$

족제비싸리 $A H N \& L E E 4335$

$\mathrm{c}, \mathrm{n}$

새콩 $A H N \&$ LEE 4795

차풀 $A H N \& L E E 4282$

개도둑놈의갈고리 $A H N \& L E E 4705$

도둑놈의갈고리 $A H N \& L E E 4418$

돌콩 $A H N \& L E E 4232$

매듭풀 $A H N \& L E E 4796$

활량나물 $A H N \& L E E 4362$

싸리 $A H N \&$ \&EE 4402

비수리 $A H N \&$ LEE 4456, 4671

참싸리 $A H N \& L E E 4322$

해변싸리 $A H N \& L E E 4643$

I, e

조록싸리 $A H N \& L E E 4723$

풀싸리 $A H N \& L E E 4578$

벌노랑이 $A H N \& L E E 4406$

칡 $A H N \& L E E 4274,4691$

아까시나무 $A H N \& L E E 4450$

$\mathrm{c}, \mathrm{n}$

고삼 $A H N \&$ \&EE 4458

토끼풀 $A H N \& L E E 4407,4590$

n

갈퀴나물 $A H N \&$ LEE 4363

노랑갈퀴 $A H N \& L E E 4084$

III, e

네잎갈퀴나물 $A H N \& L E E 4389$

나비나물 $A H N \& L E E 4560$

등 $A H N \&$ \&EE 4213

IV, c

보리수나무 $A H N \& L E E 4228,4243$

미국좀부처꽃 $A H N \& L E E 4434$

$\mathrm{n}$

털부처꽃 $A H N \& L E E 4254,4457$

쇠털이슬 $A H N$ \& $L E E 4366,4718$

I

돌바늘꽃 $A H N$ \& LEE 4252

달맞이꽃 $A H N \& L E E 4373,4707$

n

박쥐나무 $A H N \& L E E 4130$

층층나무 $A H N \& \operatorname{LEE} 4107$ 
Appendix 1. Continued.

Cornus walteri Wangerin

SANTALACEAE R. Br. 단향과

Thesium chinense Turcz.

Viscum album var. coloratum (Kom.) Ohwi

CELASTRACEAE R. Br. 노박덩굴과

Celastrus flagellaris Rupr.

Celastrus orbiculatus Thunb.

Euonymus alatus (Thunb.) Siebold

Euonymus maackii Rupr.

Euonymus oxyphyllus Miq.

Tripterygium regelii Sprague \& Takeda

EUPHORBIACEAE Juss. 대극과

Acalypha australis L.

Euphorbia ebracteolata Hayata

Euphorbia maculata L.

Euphorbia pekinensis Boiss.

Euphorbia supina Raf.

Phyllanthus ussuriensis Rupr. \& Maxim.

Securinega suffruticosa (Pall.) Rehder

RHAMNACEAE Juss. 갈매나무과

Rhamnus yoshinoi Makino

VITACEAE Juss. 포도과

Parthenocissus tricuspidata (Siebold \& Zucc.) Planch.

Vitis amurensis Rupr.

POLYGALACEAE Hoffmanns. \& Link 원지과

Polygala japonica Houtt.

STAPHYLEACEAE Martinov 고추나무과

Staphylea bumalda DC.

ACERACEAE Juss. 단풍나무과

Acer palmatum Thunb.

Acer pictum var. mono (Maxim.) Franch.

Acer pseudosieboldianum (Pax) Kom.

Acer tataricum ssp. ginnala (Maxim.) Wesm.

Acer triflorum Kom.

ANACARDIACEAE R. Br. 옻나무과

Rhus javainca $\mathrm{L}$.

Toxicodendron trichocarpum (Miq.) Kuntze

SIMAROUBACEAE DC. 소태나무과

Ailanthus altissima (Mill.) Swingle

Picrasma quassioides (D. Don) Benn.
말채나무 $A H N \& L E E 4360$

제비꿀 $A H N \&$ LEE 4797

겨우살이 $A H N \& L E E 4003$

푼지나무 $A H N \& L E E 4798$

노박덩굴 $A H N \& L E E 4271,4697$

화살나무 $A H N \& L E E$ 4205, 4251

좁은잎참빗살나무 $A H N \& L E E 4200,4689$

I

참회나무 $A H N \& L E E 4139$

미역줄나무 $A H N \& L E E 4311,4398$

I

깨풀 $A H N \& L E E 4513$

붉은대극 $A H N \& L E E 4058$

큰땅빈대 $A H N \& L E E 4259,4656$

대극 $A H N \& L E E 4173$

애기땅빈대 $A H N \& L E E 4343$

여우주머니 $A H N \& L E E 4801$

광대싸리 $A H N \& L E E$ 4270, 4312

짝자래나무 $A H N \& L E E 4120,4138$

담쟁이덩굴 $A H N \& L E E 4370,4715$

왕머루 $A H N$ \& LEE 4802

애기풀 $A H N \& L E E 4066,4531$

고추나무 $A H N \& L E E$ 4190, 4374

단풍나무 $A H N \& L E E 4336$

III, c

고로쇠나무 $A H N \& L E E 4207$

당단풍나무 $A H N \& L E E 4176,4318$

신나무 $A H N \&$ LEE 4192

복자기 $A H N \& L E E 4099$

III, Nor

붉나무 $A H N \& L E E 4332,4700$

개옻나무 $A H N \& L E E 4269,4530$

가중나무 $A H N \& L E E 4803$

$\mathrm{n}$
III, Nor

$\mathrm{n}$

N

RUTACEAE Juss. 운향과 
Appendix 1. Continued.

Dictamnus dasycarpus Turcz.

Phellodendron amurense Rupr.

Zanthoxylum piperitum (L.) DC.

Zanthoxylum schinifolium Siebold \& Zucc.

OXALIDACEAE R. Br. 괭이밥과

Oxalis corniculata L.

GERANIACEAE Juss. 쥐손이풀과

Geranium nepalense Sweet

Geranium sibiricum L.

Geranium thunbergii Lindl. \& Paxton

BALSAMINACEAE A. Rich. 봉선화과

Impatiens textori Miq.

ARALIACEAE Juss. 두릅나무과

Aralia cordata Thunb.

Aralia elata (Miq.) Seem.

Eleutherococcus sessiliflorus (Rupr. \& Maxim.) S. Y. Hu

Kalopanax septemlobus (Thunb.) Koidz.

APIACEAE Lindl. 미나리과

Angelica decursiva (Miq.) Franch. \& Sav.

Angelica gigas Nakai

Angelica polymorpha Maxim.

Cryptotaenia japonica Hassk.

Cymopterus melanotilingia (H. Boissieu) C. Y. Yoon

Oenanthe javanica (Blume) DC.

Ostericum grosseserratum (Maxim.) Kitag.

Sillaphyton podagraria (H. Boissieu) Pimenov.

Peucedanum terebinthaceum (Trevir.) Turcz.

Pimpinella brachycarpa (Kom.) Nakai

Sanicula chinensis Bunge

Sium ninsi L.

Torilis scabra (Thunb.) DC.

\section{ASTERIDAE 국화아강}

GENTIANACEAE Juss. 용담과

Gentiana scabra Bunge

Gentiana zollingeri Fawc.

Gentiana triflora for. japonica (Kusn.) W. T. Lee \& W. K. Paik

Swertia wilfordii A. Kern.

ASCLEPIADACEAE Borkh. 박주가리과

Cynanchum ascyrifolium (Franch. \& Sav.) Matsum.

Cynanchum nipponicum Matsum.

Cynanchum wilfordii (Maxim.) Hook. f.
백선 $A H N \& L E E 4490$

황벽나무 $A H N \& L E E 4804$

II

초피나무 $A H N \& L E E 4805$

산초나무 $A H N \& L E E$ 4202, 4523

괭이밥 $A H N \& L E E 4806$

산이질풀 $A H N \& L E E 4679$

쥐손이풀 $A H N$ \& LEE 4357

이질풀 $A H N \& L E E 4249$

물봉선 $A H N \& L E E 4683$

땅두릅 $A H N \& L E E 4376,4566$

두릅나무 $A H N \& L E E 4573$

오갈피나무 $A H N \& L E E 4807$

음나무 $A H N \&$ LEE 4699

바디나물 $A H N \& L E E 4472,4632$

당귀 $A H N \& L E E 4582$

궁궁이 $A H N \&$ LEE 4808

파드득나물 $A H N \& L E E 4809$

큰참나물 $A H N \& L E E 4558$

II

미나리 $A H N \& L E E 4246$

신감채 $A H N \& L E E$ 4562, 4594

덕우기름나물 $A H N \& L E E 4391$

IV, e

기름나물 $A H N \& L E E 4382,4763$

참나물 $A H N \& L E E 4273$

참반디 $A H N \& L E E 4487$

감자개발나물 $A H N \& L E E 4552,4740$

큰사상자 $A H N \& L E E 4387$

용담 $A H N \& L E E 4641$

큰구슬붕이 $A H N \& L E E 4067$

과남풀 $A H N$ \& $L E E 4410$

Nor

큰잎쓴풀 $A H N \& L E E 4008,4519$

V, VU

민백미꽃 $A H N \&$ LEE 4085

I

덩굴박주가리 $A H N \& L E E 4549$

III

큰조롱 $A H N$ \& $L E E 4275$ 
Appendix 1. Continued.

Metaplexis japonica (Thunb.) Makino

Tylophora floribunda Miq.

SOLANACEAE Juss. 가지과

Scopolia japonica Maxim.

Solanum lyratum Thunb.

Solanum nigrum L.

CONOVOLVULACEAE Juss. 메꽃과

Calystegia sepium (L.) R. Br.

Calystegia soldanella (L.) Roem. \& Schult.

Cuscuta japonica Choisy

Cuscuta pentagona Engelm.

Ipomoea purpurea (L.) Roth

BORAGINACEAE Juss. 지치과

Bothriospermum tenellum (Hornem.) Fisch. \& C. A. Mey.

Lithospermum erythrorhizon Siebold \& Zucc.

Trigonotis peduncularis (Trevis.) Baker \& S. Moore

Trigonotis radicans var. sericea (Maxim.) H. Hara

VERBENACEAE J. St.-Hil. 마편초과

Callicarpa japonica Thunb.

Clerodendron trichotomum Thunb.

PHRYMACEAE Schauer 파리풀과

Phryma leptostachya var. oblongifolia (Koidz.) Honda

LAMIACEAE Martinov 꿀풀과

Agastache rugosa (Fisch. \& C. A. Mey.) Kuntze

Clinopodium chinense var. parviflorum (Kudô) H. Hara

Elsholtzia ciliata (Thunb.) H. Hyl.

Elsholtzia splendens F. Maek.

Isodon inflexus (Thunb.) Kudô

Isodon serra (Maxim.) Kudô

Lamium album var. barbatum (Siebold \& Zucc.) Franch. \& Sav.

Lamium amplexicaule L.

Leonurus japonicus Houtt.

Leonurus macranthus Maxim.

Lycopus lucidus Benth.

Meehania urticifolia (Miq.) Makino

Phlomis umbrosa Turcz.

Prunella asiatica Nakai

Scutellaria dependens Maxim.

Scutellaria pekinensis var. transitra (Makino) H. W. Li

PLANTAGINACEAE Juss. 질경이과

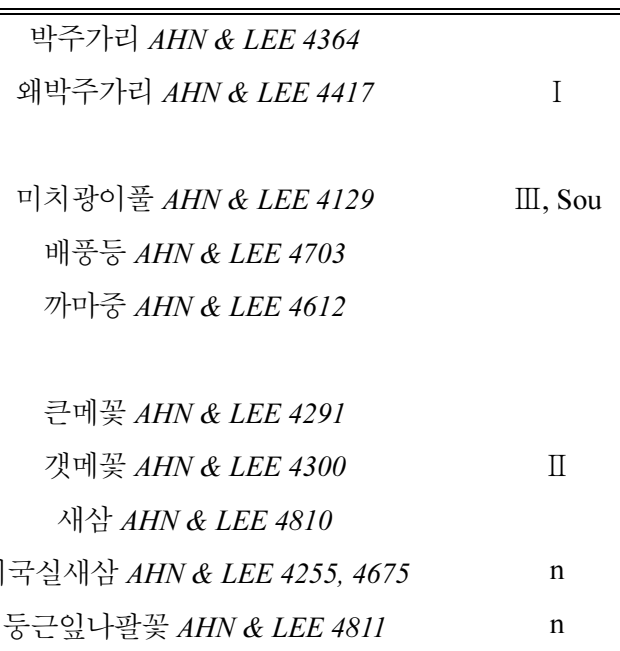

꽃받이 $A H N \&$ LEE 4674

지치 $A H N \& L E E 4352$

꽃마리 $A H N \& L E E 4045,4165$

참꽃마리 $A H N \& L E E 4812$

작살나무 $A H N$ \& $L E E$ 4313, 4739

누리장나무 $A H N \& L E E 4525$

파리풀 $A H N \& L E E 4302$

배초향 $A H N \& L E E 4377$

층층이꽃 $A H N \& L E E 4248,4481$

향유 $A H N \& L E E 4622$

꽃향유 $A H N \&$ LEE 4576, 4636

산박하 $A H N \& L E E$ 4386, 4595

자주방아풀 $A H N \& L E E 4642$

광대수염 $A H N \& L E E 4101,4607$

광대나물 $A H N \& L E E 4041,4224$

익모초 $A H N \& L E E 4350$

송장풀 $A H N \& L E E 4367$

쉽싸리 $A H N \& L E E 4316$

벌깨덩굴 $A H N \& L E E 4143$

속단 $A H N \& L E E 4372,4574$

꿀풀 $A H N \& L E E 4340$

애기골무꽃 $A H N \& L E E 4550,4726$

II 
Appendix 1. Continued.

OLEACEAE Hoffmanns. \& Link 물푸레나무과

Fraxinus rhynchophylla Hance

Ligustrum obtusifolium Siebold \& Zucc.

물푸레나무 $A H N \&$ \&EE 4239

CROPHULARIACEAE Juss. 현삼과

Melampyrum roseum var. japonicum Franch. \& Sav.

쥐똥나무 $A H N \& L E E 4240$

Melampyrum setaceum (Palib.) Nakai

Mimulus nepalensis Benth.

Paulownia coreana Uyeki

Pseudolysimachion dahuricum (Steven) Holub

Veronica arvensis $\mathrm{L}$.

Veronica persica Poir.

LENTIBULARIACEAE Rich. 통발과

Utricularia bifida $\mathrm{L}$.

CAMPANULACEAE Juss. 초롱꽃과

Adenophora stricta Miq.

Adenophora verticillata (Pall.) Fisch.

Asyneuma japonicum (Miq.) Briq.

Campanula punctata Lam.

Codonopsis lanceolata (Siebold \& Zucc.) Trautv.

Lobelia chinensis Lour.

Platycodon grandiflorum (Jacq.) A. DC.

RUBIACEAE Juss. 꼭두서니과

Asperula maximowiczii Kom.

Galium dahuricum Turcz.

Galium gracilens (A. Gray) Makino

Galium pogonanthum Franch. \& Sav.

Galium verum var. asiaticum Nakai

Rubia akane Nakai

Rubia chinensis Regel \& Maack

Rubia cordifolia var. pratensis Maxim.

LINNAEACEAE Backland 린네풀과

Zabelia biflora (Turcz.) Makino

DIERVILLACEAE Pyck 병꽃나무과

Weigela florida (Bunge) A. DC.

CAPRIFOLIACEAE Juss. 인동과

Lonicera japonica Thunb.

Lonicera maackii (Rupr.) Maxim.

Lonicera praeflorens Batalin

수염며느리밥풀 $A H N \& L E E 4488$

애기며느리밥풀 $A H N \& L E E 4328$

III, Nor

물꽈리아재비 $A H N \&$ \&EE 4518

오동나무 $A H N \& L E E 4077,4673$

구와꼬리풀 $A H N \& L E E 4685$

선개불알풀 $A H N \& L E E 4161$

큰개불알풀 $A H N \& L E E 4044$

땅귀개 $A H N \& L E E 4534$

IV

당잔대 $A H N \&$ \& $L E 4813$

층층잔대 $A H N \& L E E 4265,4459$

영아자 $A H N \& L E E 4413,4604$

초롱꽃 $A H N \& L E E 4814$

더덕 $A H N \&$ LEE 4815

수염가래꽃 $A H N \& L E E 4440$

도라지 $A H N \& L E E$ 4399, 4744

개갈퀴 $A H N \& L E E 4473,4616$

큰잎갈퀴 $A H N \&$ LEE 4086

좀네잎갈퀴 $A H N \& L E E 4816$

산갈퀴 $A H N \& L E E$ 4307, 4385

솔나물 $A H N \& L E E 4060,4321$

꼭두서니 $A H N \&$ LEE 4817

큰꼭두서니 $A H N \& L E E 4124,4381$

II

갈퀴꼭두서니 $A H N \& L E E 4818$

털댕강나무 $A H N \& L E E 4121$

III, Nor

붉은병꽃나무 $A H N \& L E E 4196$

II

인동 $A H N \&$ \&EE 4253

괴불나무 $A H N \& L E E 4116,4368$

올괴불나무 $A H N \& L E E 4017$

ADOXACEAE E. Mey. 연복초과

Adoxa moschatellina $\mathrm{L}$.

연복초 $A H N \& L E E 4040$

Sambucus racemosa ssp. sieboldiana (Miq.) H. Hara

딱총나무 $A H N \& L E E 4096$ 
Appendix 1. Continued.

VALERIANACEAE Batsch 마타리과

Patrinia scabiosifolia Trevir.

Patrinia villosa (Thunb.) Juss.

Valeriana fauriei Briq.

DIPSACACEAE Juss. 산토끼과

Dipsacus japonicus Miq.

ASTERACEAE Bercht. \& J. Presl 국화과

Ainsliaea acerifolia Sch. Bip.

Ambrosia artemisiifolia L.

Artemisia annua L.

Artemisia capillaris Thunb.

Artemisia gmelinii Stechm.

Artemisia feddei H. Lév. \& Vaniot

Artemisia japonica Thunb.

Artemisia keiskeana Miq.

Artemisia montana (Nakai) Pamp.

Artemisia princeps Pamp.

Artemisia selengensis Besser

Artemisia stolonifera (Maxim.) Kom.

Aster ageratoides Turcz.

Aster incisus Fisch.

Aster maackii Regel

Aster meyendorffii (Regel et Maack) Voss.

Aster pilosus L.

Aster scaber Thunb.

Aster tataricus L. f.

Atractylodes ovata (Thunb.) DC.

Bidens bipinnata L.

Bidens frondosa $\mathrm{L}$.

Bidens parviflora Willd.

Carduus crispus L.

Carpesium divaricatum Siebold \& Zucc.

Centipeda minima (L.) A. Braun \& Aschers.

Cirsium pendulum DC.

Conyza canadensis (L.) Cronquist

Coreopsis alternifolia L.

Coreopsis lanceolata $\mathrm{L}$.

Cosmos bipinnatus Cav.

Crepidiastrum chelidoniifolium (Makino) J. H. Pak \& Kawano

Crepidiastrum denticulatum (Houtt.) J. H. Pak \& Kawano

Crepidiastrum sonchifolium (Bunge) J. H. Pak \& Kawano
마타리 $A H N \& L E E 4531,4653$

뚝갈 $A H N \& L E E 4272,4579$

쥐오줌풀 $A H N \& L E E 4852$

산토끼꽃 $A H N \& L E E 4371$

III, Nor

단풍취 $A H N \& L E E 4733$

돼지풀 $A H N$ \& $L E E 4823$

n, d

개똥쑥 $A H N \& L E E 4820$

사철쑥 $A H N \& L E E$ 4262, 4655

더위지기 $A H N \& L E E 4609$

뺑쑥 $A H N$ \& LEE 4237, 4568

제비쏙 $A H N \& L E E 4620$

맑은대쑥 $A H N \& L E E 4344,4727$

산쑥 $A H N \&$ LEE 4619

丛 $A H N$ \& LEE 4654

물쑥 $A H N \& L E E 4821$

넓은잎외잎쑥 $A H N \& L E E 4264,4596$

까실쑥부쟁이 $A H N \& L E E 4572$

가새쑥부쟁이 $A H N \& L E E 4492$

좀개미취 $A H N$ \& $L E E 4640$

III

개쑥부쟁이 $A H N \& L E E 4693$

미국쑥부쟁이 $A H N \& L E E 4684$

참취 $A H N$ \& $L E E 4317,4713$

개미취 $A H N \& L E E 4580$

삽주 $A H N \& L E E 4480,4738$

도깨비바늘 $A H N \& L E E$ 4423, 4605

미국가막사리 $A H N \& L E E 4611$

n

까치발 $A H N$ \& LEE 4394

지느러미엉겅퀴 $A H N \& L E E 4209$

n

긴담배풀 $A H N \& L E E 4369,4390$

중대가리풀 $A H N \& L E E 4498$

c

큰엉겅퀴 $A H N \& L E E 4826$

망초 $A H N$ \& $L E E 4238,4288$

I, Nor

$\mathrm{n}$

나래가막사리 $A H N \& L E E 4405$

$\mathrm{c}, \mathrm{n}$

큰금계국 $A H N \& L E E 4470$

$\mathrm{c}, \mathrm{n}$

코스모스 $A H N \& L E E 4830$

$\mathrm{c}, \mathrm{n}$

이고들 빼기 $A H N \& L E E 4633,4745$

고들빼기 $A H N \& L E E 4115,4404$ 
Appendix 1. Continued.

Dendranthema boreale (Makino) Kitam.

Dendranthema zawadskii (Herbich) Tzvelev

Echinops setifer Iljin

Erechtites hieracifolia (L.) DC.

Erigeron annuas (L.) Pers.

Eupatorium japonicum Thunb.

Eupatorium makinoi var. oppositifolium (Koidz.) Kawah. \& Yahara

Galinsoga parviflora Cav.

Galinsoga quaderiradiata Ruiz \& Pav.

Helianthus tuberosus L.

Hemistepta lyrata Bunge

Hieracium umbellatum $\mathrm{L}$.

Inula salicia var. asiatica Kitam.

Ixeridium dentatum (Thunb.) Tzvelev

Ixeris polycephala Cass.

Lactuca indica var. laciniata for. indivisa (Maxim.) H. Hara

Lactuca raddeana Maxim.

Lactuca scariola L.

Lactuca triangulata Maxim.

Leibnitzia anandria (L.) Turcz.

Ligularia fischeri (Ledeb.) Turcz.

Petasites japonicus (Siebold \& Zucc.) Maxim.

Picris hieracioides var. koreana (Kitam.) Kitam.

Rudbeckia hirta var. pulcherrima Farw.

Saussurea gracilis Maxim.

Saussurea macrolepis (Nakai) Kitam.

Saussurea pulchella (Fisch.) Colla

Senecio vulgaris L.

Serratula coronata ssp. insularis (Iljin) Kitam.

Sigesbeckia glabrescens Makino

Sigesbeckia pubescens Makino

Solidago virgaurea ssp. asiatica $\mathrm{H}$. Hara

Sonchus asper (L.) Hill.

Syneilesis palmata (Thunb.) Maxim.

Synurus excelsus (Makino) Kitam.

Tagetes minuta L.

Taraxacum coreanum Nakai

Taraxacum mongolicum Hand.-Mazz.

Taraxacum officinale F. H. Wigg.

Tephroseris kirilowii (DC.) Holub

Xanthium italicum Moretti
산국 $A H N \& L E E 4599$

산구절초 $A H N \& L E E 4395,4762$

절굿대 $A H N \& L E E 4356$

붉은서나물 $A H N \& L E E 4634$

개망초 $A H N \& L E E 4333,4625$

등골나물 $A H N \& L E E 4326$

벌등골나물 $A H N \& L E E 4556$

별꽃아재비 $A H N \& L E E 4512$

$\mathrm{n}$

털별꽃아재비 $A H N \&$ LEE 4289

뚱딴지 $A H N \& L E E 4822$

지칭개 $A H N \& L E E 4117$

조밥나물 $A H N \& L E E 4460$

버들금불초 $A H N \& L E E 4503$

씀바귀 $A H N \& L E E 4824$

벌씀바귀 $A H N$ \& LEE 4215

가는잎왕고들 빼기 $A H N \& L E E 4451$

산씀바귀 $A H N \& L E E$ 4397, 4419

가시상치 $A H N \& L E E 4829$

두메고들빼기 $A H N \& L E E 4825$

솜나물 $A H N \& L E E 4827$

곰취 $A H N \& L E E 4828$

머위 $A H N \& L E E 4020$

쇠서나물 $A H N \& L E E 4379$

원추천인국 $A H N \& L E E 4375$

은분취 $A H N \& L E E 4584$

각시서덜취 $A H N \& L E E 4557$

각시취 $A H N$ \& $L E E 4586$

개쑥갓 $A H N$ \& $L E E 4046,4511$

산비장이 $A H N \& L E E 4747$

진득찰 $A H N \& L E E 4608$

털진득찰 $A H N \& L E E 4831$

미역취 $A H N \& L E E 4721$

큰방가지똥 $A H N \& L E E 4090$

n

우산나물 $A H N \& L E E 4476,4737$

큰수리취 $A H N \& L E E 4564$

만수국아재비 $A H N \& L E E 4832$

n

흰민들레 $A H N \& L E E 4195$

털민들레 $A H N \&$ LEE 4172

서양민들레 $A H N \& L E E 4048$

n

솜방망이 $A H N \& L E E 4075$

가시도꼬마리 $A H N \& L E E 4613$ e

n 
Appendix 1. Continued.

Youngia japonica (L.) DC.

LILIOPSIDA 백합강

ALISMATIDAE 택사아강

ALISMATACEAE Vent. 택사과

Alisma canaliculatum A. Braun \& C. D. Bouché

Alisma orientale (Sam.) Juz.

Sagittaria aginashi Makino

POTAMOGETONACEAE Bercht. \& J. Presl 가래과

Potamogeton distinctus A. Benn.

Potamogeton pusillus $\mathrm{L}$.

ARECIDAE 종려아강

ARACEAE Juss. 천남성과

Arisaema amurense Maxim.

Arisaema peninsulae Nakai

Pinellia ternata (Thunb.) Breitenb.

Symplocarpus nipponicus Makino

LEMNACEAE Martinov 개구리밥과

Lemna perpusilla Torr.

Spirodela polyrhiza (L.) Schleid.

COMMELINIDAE 닭의장풀아강

COMMELINACEAE Mirb. 닭의장풀과

Commelina communis $\mathrm{L}$.

Murdannia keisak (Hassk.) Hand.-Mazz.

Streptolirion volubile Edgew.

Tradescantia ohioensis Raf.

ERIOCAULACEAE Martinov 곡정초과

Eriocaulon miquelianum Körn.

JUNCACEAE Juss. 골풀과

Juncus diastrophanthus Buchenau

Juncus effusus var. decipiens Buchenau

Juncus krameri Franch. \& Sav.

Juncus papillosus Franch. \& Sav.

Juncus tenuis Willd.

Juncus wallichianus Laharpe

Luzula capitata (Miq.) Kom.

CYPERACEAE Juss. 사초과

Bulbostylis barbata (Rottb.) C. B. Clarke

Carex bostrychostigma Maxim.

Carex breviculmis R. Br.

Carex ciliatomarginata Nakai

Carex dickinsii Franch. \& Sav.
뽀리뱅이 $A H N \& L E E 4089,4219$

$\begin{array}{cc}\text { 택사 } A H N \& L E E 4494 & \text { II } \\ \text { 질경이택사 } A H N \& L E E 4461 & \text { II } \\ \text { 보풀 } A H N \& L E E 4424,4708 & \text { I }\end{array}$

가래 $A H N \& L E E 4652$

실말 $A H N \&$ LEE 4725, 4728

둥근잎천남성 $A H N \& L E E 4156$

점백이천남성 $A H N \& L E E 4158$

반하 $A H N \& L E E 4833$

애기앉은부채 $A H N \& L E E 4010$

III, Nor

좀개구리밥 $A H N \& L E E 4659$

개구리밥 $A H N \& L E E 4658$

닭의장풀 $A H N \& L E E 4314$

사마귀풀 $A H N \& L E E 4834$

덩굴닭의장풀 $A H N \& L E E 4353$

자주달개비 $A H N \& L E E 4118$

$\mathrm{c}, \mathrm{n}$

개수염 $A H N \& L E E 4499,4528$

별날개골풀 $A H N \& L E E 4504$

골풀 $A H N \& L E E 4257,4330$

비녀골풀 $A H N \& L E E 4471,4662$

청비녀골풀 $A H N \& L E E 4329$

길골풀 $A H N \& L E E 4835$

눈비녀골풀 $A H N \& L E E 4447$

뀡의밥 $A H N \& L E E 4141$

모기골 $A H N \& L E E 4663$

길뚝사초 $A H N \& L E E 4169$

청사초 $A H N \& L E E 4162$

털대사초 $A H N \&$ LEE 4021

도깨비사초 $A H N \& L E E 4529$ 
Appendix 1. Continued.

Carex fernaldiana H. Lév. \& Vaniot

Carex forficula Franch. \& Sav.

Carex gifuensis Franch.

Carex heterolepis Bunge

Carex humilis var. nana (H. Lév. \& Vaniot) Ohwi

Carex jaluensis Kom.

Carex japonica Thunb.

Carex kamagariensis K. Okamoto

Carex laevissima Nakai

Carex lanceolata Boott

Carex lasiolepis Franch.

Carex leiorhyncha C.A. Mey.

Carex maximowiczii Miq.

Carex mira Kük.

Carex neurocarpa Maxim.

Carex okamotoi Ohwi

Carex oxyandra (Franch. \& Sav.) Kudô

Carex pediformis var. pedunculata Maxim.

Carex planiculmis Kom.

Carex polyschoena H. Lév. \& Vaniot

Carex pumila Thunb.

Carex sabynensis Kunth

Cyperus amuricus Maxim.

Cyperus difformis $\mathrm{L}$.

Cyperus globosus Forssk.

Cyperus iria L.

Cyperus microiria Steud.

Cyperus orthostachyus Franch. \& Sav.

Cyperus sanguinolentus Vahl

Eleocharis congesta var. japonica (Miq.) T. Koyama

Eleocharis kuroguwai Ohwi

Eleocharis wichurai Boeck.

Fimbristylis autumnalis (L.) Roem. \& Schult.

Fimbristylis tristachya var. subbispicata (Nees \& Meyen) T. Koyama

Kyllinga brevifolia Rottb.

Rhynchospora fujiiana Makino

Scirpus hotarui Ohwi

Scirpus juncoides Roxb.

Scirpus karuizawensis Makino

Scirpus mitsukurianus Makino

Scirpus triangulatus Roxb.
실사초 $A H N$ \& $L E E 4082$

산뚝사초 $A H N \& L E E 4062,4157$

애기감둥사초 $A H N \& L E E 4151$

산비늘사초 $A H N \& L E E 4071,4189$

가는잎그늘사초 $A H N \& L E E 4033$

참삿갓사초 $A H N \& L E E 4083,4109$

개찌버리사초 $A H N \& L E E 4168$

좀목포사초 $A H N \& L E E 4163$

애괭이사초 $A H N \& L E E 4152$

그늘사초 $A H N \& L E E 4023$

난사초 $A H N \& L E E 4019$

III

산괭이사초 $A H N \& L E E 4226$

왕비늘사초 $A H N \& L E E 4065,4539$

꼬랑사초 $A H N \&$ LEE 4052, 4092

괭이사초 $A H N \& L E E 4365,4445$

지리대사초 $A H N \& L E E 4149$

언덕사초 $A H N \& L E E 4093$

왕그늘사초 $A H N \& L E E 4072$

그늘흰사초 $A H N \& L E E 4081$

가지청사초 $A H N \& L E E 4183$

좀보리사초 $A H N \& L E E 4444$

실청사초 $A H N \& L E E 4069$

방동산이 $A H N \& L E E 4836$

알방동산이 $A H N \& L E E 4439,4666$

드렁방동산이 $A H N \& L E E 4682$

참방동산이 $A H N \& L E E 4431,4667$

금방동산이 $A H N \& L E E$ 4432, 4506

쇠방동산이 $A H N \& L E E 4501,4645$

방동산이대가리 $A H N \& L E E 4644$

바늘골 $A H N \& L E E 4500$

올방개 $A H N \& L E E 4465$

좀네모골 $A H N \& \operatorname{LEE~4348,4532}$

애기하늘지기 $A H N \& L E E 4664$

꼴하늘지기 $A H N \& L E E 4468$

가시파대가리 $A H N \& L E E 4661$

좀고양이수염 $A H N \& L E E 4533$

좀올챙이골 $A H N \& L E E 4495,4731$

올챙이고랭이 AHN \& LEE 4261, 4441

솔방울고랭이 $A H N \&$ LEE 4548

솔방울골 $A H N \& L E E 4426,4446$

송이고랭이 $A H N \& L E E 4704$ 
Appendix 1. Continued.

Scirpus wichurai var. asiaticus (Beetle) Ohwi

POACEAE Barnhart 화본과

Agropyron ciliare (Trin.) Franch.

Agropyron tsukushiense var. transiens (Hack.) Ohwi

Agrostis clavata var. nukabo Ohwi

Alopecurus aequalis Sobol.

Arthraxon hispidus (Thunb.) Makino

Arundinella hirta (Thunb.) Tanaka

Bromus japonicus Thunb.

Bromus pauciflorus Hack.

Bromus tectorum $\mathrm{L}$.

Calamagrostis arundinacea (L.) Rroth

Calamagrostis langsdorffii (Link.) Trin.

Cleistogenes hackelii (Honda) Honda

Cymbopogon tortilis ssp. goeringii (Steud.) T. Koyama

Dactylis glomerata L.

Diarrhena mandshurica Maxim.

Digitaria sanguinalis (L.) Scop.

Echinochloa crusgalli (L.) P. Beauv.

Eleusine indica (L.) Gaertn.

Eragrostis curvula (Schrad.) Nees

Eragrostis ferruginea (Thunb.) P. Beauv.

Eriochloa villosa (Thunb.) Kunth

Festuca arundinacea Schreb.

Festuca ovina L.

Glyceria leptolepis Ohwi

Hemarthria compressa var. japonica (Hack.) Y.N. Lee

Hierochloe odorata (L.) P. Beauv.

Isachne globosa (Thunb.) Kuntze

Leersia oryzoides (L.) Sw.

Melica onoei Franch. \& Sav.

Microstegium vimineum var. polystachyum (Franch. \& Sav.) Ohwi

Miscanthus sinensis Andersson

Moliniopsis japonica (Hack.) Hayata

Muhlenbergia hugelii Trin.

Muhlenbergia japonica Steud.

Oplismenus undulatifolius (Ard.) Roem. \& Schult.

Panicum bisulcatum Thunb.

Paspalum thunbergii Steud.

Pennisetum alopecuroides (L.) Spreng.

Phragmites communis Trin.
방울고랭이 $A H N \& L E E$ 4347, 4546

속털개밀 $A H N \&$ LEE 4837

개밀 $A H N \&$ \&EE 4838

겨이삭 $A H N \& L E E 4153,4349$

뚝새풀 $A H N \& L E E 4145$

조개풀 $A H N \& L E E 4639$

새 $A H N \& L E E 4319,4540$

참새귀리 $A H N \& L E E 4076$

꼬리새 $A H N \&$ \&EE 4449

털빕새귀리 $A H N \& L E E 4211$

n

실새풀 $A H N \& L E E$ 4393, 4479

산새풀 $A H N \& L E E 4244$

대새풀 $A H N \& L E E 4455$

개솔새 $A H N \& L E E 4637$

오리새 $A H N$ \& $L E E 4078$

$\mathrm{n}$

껍질용수염풀 $A H N \& L E E 4296,4581$

바랭이 $A H N \&$ LEE 4624

돌피 $A H N \& L E E 4414,4665$

왕바랭이 $A H N \& L E E 4435$

능수참새그령 $A H N \& L E E 4840$

n

그령 $A H N \& L E E 4361,4577$

나도개피 $A H N \& L E E 4267$

큰김의털 $A H N \& L E E$ 4087, 4276

김의털 $A H N \& L E E 4524$

왕미꾸리광이 $A H N \& L E E 4245$

II

쇠치기풀 $A H N \& L E E 4839$

향모 $A H N \& L E E 4210$

기장대풀 $A H N \& L E E 4538$

좀겨풀 $A H N \& L E E$ 4496, 4686

쌀새 $A H N$ \& LEE 4351

큰듬성이삭새 $A H N \& L E E 4627$

억새 $A H N \& L E E$ 4400, 4672

진퍼리새 $A H N$ \& $L E E 4553$

큰쥐꼬리새 $A H N \& L E E$ 4514, 4600

쥐꼬리새 $A H N$ \& $L E E 4617$

주름조개풀 $A H N \& L E E$ 4309, 4598

개기장 $A H N \& L E E 4629$

참새피 $A H N \& L E E 4850$

수크령 $A H N \& L E E 4258,4649$

갈대 $A H N \& L E E 4680$ 
Appendix 1. Continued.

Phragmites japonica Steud.

Phyllostachys nigra var. henonis (Mitford) Rendle

Poa compressa L.

Poa matsumurae Hack.

Sacciolepis indica (L.) Chase

Sasa borealis (Hack.) Makino \& Shibata

Sasa japonica (Steud.) Makino

Setaria faberi R.A.W. Herrm.

Setaria glauca (L.) P. Beauv.

Setaria viridis (L.) P. Beauv.

Spodiopogon cotulifer (Thunb.) Hack.

Spodiopogon sibiricus Trin.

Stipa pekinensis Hance

Themeda triandra ssp. japonica (Willd.) T. Koyama

TYPHACEAE Juss. 부들과

Typha angustifolia $\mathrm{L}$.

Typha orientalis C. Presl.

LILIIDAE 백합아강

LILIACEAE Juss. 백합과

Allium monanthum Maxim.

Asparagus oligoclonos Maxim.

Disporum smilacinum A. Gray

Erythronium japonicum Decne.

Gagea lutea (L.) Ker Gawl.

Heloniopsis koreana S. Fuse, N. S. Lee \& M. N. Tamura

Hosta capitata (Koidz.) Nakai

Lilium lancifolium Thunb.

Polygonatum humile Maxim.

Polygonatum inflatum Kom.

Polygonatum involucratum (Franch. \& Sav.) Maxim.

Polygonatum odoratum var. pluriflorum (Miq.) Ohwi

Scilla scilloides (Lind1.) Druce

IRIDACEAE Juss. 붓꽃과

Iris ensata var. spontanea (Makino) Nakai

Iris rossii Baker

Iris sanguinea Hornem.

SMILACAEAE Vent. 청미래덩굴과

Smilax china L.

Smilax nipponica Miq.

Smilax riparia A. DC.

Smilax sieboldii Miq.

$\begin{array}{ll}\text { 달뿌리풀 } A H N \& L E E 4651 & \\ \text { 솜대 } A H N \& L E E 4561 & \mathrm{c} \\ \text { 졸포아풀 } A H N \& L E E 4155,4305 & \mathrm{n} \\ \text { 가는포아풀 } A H N \& L E E 4160 & \text { II }\end{array}$

좀물뚝새 $A H N \& L E E 4848$

조릿대 $A H N$ \& LEE 4696

이대 $A H N \& L E E 4841$

가을강아지풀 $A H N \& L E E 4436$

금강아지풀 $A H N \& L E E 4846$

강아지풀 $A H N \& L E E 4323$

기름새 $A H N \& L E E 4250$

큰기름새 $A H N \& L E E 4325$

나래새 $A H N \& L E E 4411,4720$

솔새 $A H N \& L E E 4256,4638$

애기부들 $A H N \& L E E 4427$

부들 $A H N \& L E E 4247$

달래 $A H N \& L E E 4024$

방울비짜루 $A H N \& L E E 4201$

애기나리 $A H N \& L E E$ 4147, 4474

얼레지 $A H N \& L E E 4036$

중의무릇 $A H N \& L E E 4011$

처녀치마 $A H N \& L E E 4028$

II

일월비비추 $A H N \& L E E 4346$

참나리 $A H N \& L E E 4281$

각시둥굴레 $A H N \& L E E 4430$

퉁둥굴레 $A H N \& L E E$ 4074, 4134

용둥굴레 $A H N \& L E E$ 4103, 4293

둥굴레 $A H N \& L E E 4068$

무릇 $A H N \& L E E 4464$

꽃창포 $A H N$ \& $L E E 4551$

II

각시붓꽃 $A H N \& L E E 4059$

붓꽃 $A H N \& L E E 4327$

청미래덩굴 $A H N \& L E E 4849$

선밀나물 $A H N \& L E E 4845$

밀나물 $A H N \& L E E 4847$

청가시덩굴 $A H N \& L E E 4844$ 
Appendix 1. Continued.

DIOSCOREACEAE R. Br. 마과

Dioscorea japonica Thunb.

Dioscorea nipponica Makino

Dioscorea tokoro Makino

ORCHIDACEAE Juss. 난초과

Amitostigma gracilis (Blume) Schltr.

Habenaria linearifolia Maxim.

Liparis kumokiri F. Maek.

Oreorchis patens (Lindl.) Lindl.
참마 $A H N \& L E E 4278$

부채마 $A H N \& L E E 4383,4712$

도꼬로마 $A H N$ \& $L E E 4843$

병아리난초 $A H N \& L E E 4842$

잠자리난초 $A H N \& L E E 4535$

옥잠난초 $A H N \& L E E 4310$

감자난초 $A H N \& L E E 4146$

V·IV·IIIJIIJI, floristic target speiceis grade; VU·NT, rare plant grade; c, cultural plant; d, disturbing plnat; e, endemic plant; Nor, northern plant; Sou, southern plant; Ab, arctic-boreal; Bo, boreal; Bt, boreal-temperate; Te, temperate; Tes, temperate-subtropical; St, subtropicaltropical; $\mathrm{Su}$, subtropical; $\mathrm{Mz}$, multi zone. 